
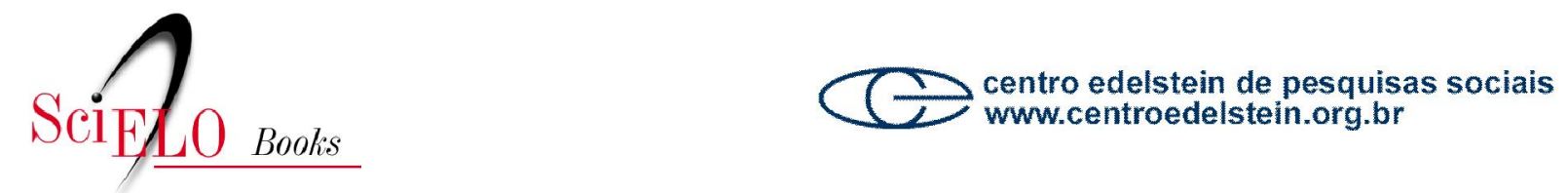

\title{
Violência e cultura no Brasil
}

\author{
Ruben George Oliven
}

SciELO Books / SciELO Livros / SciELO Libros

OLIVEN, RG. Violência e cultura no Brasil [online]. Rio de Janeiro: Centro Edelstein de Pesquisa Social, 2010, 94p. ISBN 978-85-7982-006-9. Available from SciELO Books $<$ http://books.scielo.org $>$.

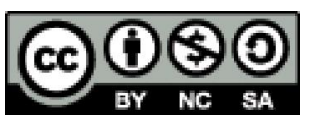

All the contents of this chapter, except where otherwise noted, is licensed under a Creative Commons Attribution-Non Commercial-ShareAlike 3.0 Unported.

Todo o conteúdo deste capítulo, exceto quando houver ressalva, é publicado sob a licença Creative Commons Atribuição Uso Não Comercial - Partilha nos Mesmos Termos 3.0 Não adaptada.

Todo el contenido de este capítulo, excepto donde se indique lo contrario, está bajo licencia de la licencia Creative Commons Reconocimento-NoComercial-CompartirIgual 3.0 Unported. 


\section{BIBLIOTECA VIRTUAL DE CIÊNCIAS HUMANAS}

VIOLÊNCIA E CULTURA NO BRASIL

\section{Ruben George Oliven}




\section{Ruben George Oliven}

\section{Violência e Cultura no Brasil}

Rio de Janeiro

2010

7 centro edelstein de pesquisas sociais

www.centroedelstein.org.kr 


\section{Sumário}

Esta publicação é parte da Biblioteca Virtual de Ciências Humanas do Centro Edelstein de Pesquisas Sociais - www.bvce.org

Copyright (c) 2010, Ruben George Oliven

Copyright (c) 2010 desta edição on-line: Centro Edelstein de Pesquisas Sociais Ano da última edição: 1989

Nenhuma parte desta publicação pode ser reproduzida ou transmitida por qualquer meio de comunicação para uso comercial sem a permissão escrita dos proprietários dos direitos autorais. A publicação ou partes dela podem ser reproduzidas para propósito não-comercial na medida em que a origem da publicação, assim como seus autores, seja reconhecida.

ISBN 978-85-7982-006-9

Centro Edelstein de Pesquisas Sociais www.centroedelstein.org.br

Rua Visconde de Pirajá, 330/1205

Ipanema - Rio de Janeiro - RJ

CEP: 22410-000. Brasil

Contato: bvce@centroedelstein.org.br
PREFÁCIO

\section{PRIMEIRA PARTE}

Capítulo I

A Violência como Mecanismo de Dominação e como Estratégia de

Sobrevivência

Capítulo II

As Vítimas da Violência no Brasil

\section{SEGUNDA PARTE}

Capítulo III

A Malandragem na Música Popular Brasileira

Capítulo IV

As Metamorfoses da Cultura Brasileira

\section{Capítulo V}

A Cultura Brasileira e a Identidade Nacional na Década de Oitenta

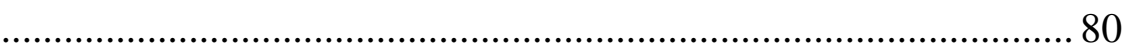

BIBLIOGRAFIA 


\section{PREFÁCIO}

O título deste livro - Violência e Cultura no Brasil - poderia levar o leitor a imaginar que estou procurando explicar a violência em nossa sociedade a partir de sua cultura. Trata-se, na verdade, de dois temas distintos que correspondem a meus interesses teóricos e às atividades de pesquisa que desenvolvo no Mestrado em Antropologia, Política e Sociologia da Universidade Federal do Rio Grande do Sul com o apoio desta Universidade, do CNPq (Conselho Nacional de Desenvolvimento Científico e Tecnológico) e da FINEP (Financiadora de Estudos e Projetos).

O tema da violência é tratado nos dois capítulos iniciais, sendo uma decorrência natural de meu interesse pelas mudanças associadas ao processo de urbanização no Brasil, assunto ao qual venho me dedicando há vários anos e que se consubstanciou em minha tese de doutorado publicada em 1980 pela Editora Vozes, sob o título de Urbanização e Mudança Social no Brasil. Nestes capítulos iniciais, discuto a existência de uma violência especificamente urbana e analiso o significado do tão propalado aumento da violência em nossas grandes cidades, procurando mostrar a utilização ideológica e a dramatização que este assunto vem experimentando recentemente. $\mathrm{O}$ primeiro capítulo analisa a violência como mecanismo de dominação e como estratégia de sobrevivência, e o segundo indaga quem são as vítimas da violência no Brasil.

A segunda parte do livro constitui-se em uma reflexão sobre a cultura no Brasil, tema que passei a estudar de forma sistemática mais recentemente. O último capítulo de Urbanização e Mudança Social no Brasil, "Classe e Cultura em Cidades Brasileiras", já significava uma ponte na direção desta temática, na medida em que procurava problematizar a maneira pela qual a dominação de classe é refletida na cultura e por ela mediada em cidades brasileiras.

"A Malandragem na Música Popular Brasileira”, o terceiro capítulo do presente livro, é uma tentativa de resgatar um tema recorrente em nossa cultura. Na música popular brasileira, a gênese da malandragem está associada à rejeição do trabalho e corresponde à formação de uma sociedade urbano-industrial. Procuro mostrar a evolução deste tema desde a década de vinte até nossos dias, salientando como a malandragem, apesar do reduzido espaço social que lhe sobrou, permanece enquanto símbolo de identidade nacional.

A questão da transformação de manifestações culturais, inicialmente restritas a certos grupos e classes sociais, em símbolos nacionais, é aprofundada no quarto capítulo que examina um aspecto fundamental para a compreensão de nossa sociedade: a dinâmica da produção e do consumo da cultura no Brasil. Detenho-me, em especial, no fenômeno da apropriação de expressões culturais específicas a certos grupos sociais por parte do resto da sociedade e sua recodificação e introdução num novo circuito semântico. Neste sentido, proponho ser justamente no processo de reelaboração de manifestações culturais e sua subsequente transformação em símbolos de identidade nacional que reside uma das peculiaridades da dinâmica cultural brasileira.

O último capítulo examina a cultura brasileira e a identidade nacional na década de oitenta, retomando algumas das antigas questões sobre o tema e analisando a maneira pela qual são reatualizadas no presente. Temas como a especificidade e o grau de autenticidade do que é considerado cultura brasileira, a contribuição que diferentes classes sociais prestariam à formação do que é chamado de identidade nacional, os produtores de cultura tidos como válidos, a relação que existe entre as classes sociais no processo de produção cultural e, em última análise, o que é considerado cultura brasileira também são enfatizados. Em relação ao presente, procuro mostrar como, depois de 1964, o panorama cultural se alterou substancialmente no Brasil, verificando-se que o Estado usa a cultura como um espaço para a construção de um projeto de hegemonia. $\mathrm{O}$ papel do Estado em relação à cultura no Brasil é, entretanto, complexo: ele não é apenas o agente de repressão e de censura, mas também o incentivador da produção cultural e, acima de tudo, o criador de uma imagem integrada do Brasil que tenta se apropriar do monopólio da memória nacional. 
Organizei o conteúdo deste livro de tal modo que ele pode ser lido como um todo ou por capítulos, sem prejuízo do seu sentido. Tive oportunidade de apresentar e discutir partes dele, sob forma de comunicação, em diversos encontros acadêmicos. Sou grato aos organizadores dessas atividades pelo estimulante intercâmbio intelectual que me propiciaram.

A reflexão que deu origem aos textos deste livro não é resultante unicamente de um trabalho individual, mas da convivência com colegas, alunos e companheiros de encontros científicos que muito contribuíram para o desenvolvimento das ideias aqui apresentadas. As pessoas envolvidas neste processo são tantas que tentar citá-las fatalmente envolveria o risco de omitir nomes. Prefiro, pois, expressar minha gratidão deixando-os no anonimato coletivo. 


\section{Capítulo I}

\section{A VIOLÊNCIA COMO MECANISMO DE DOMINAÇÃO E COMO ESTRATÉGIA DE SOBREVIVÊNCIA*}

Quando se pretende analisar a questão da violência nas grandes cidades brasileiras, a base da qual se deve partir é do fato de que, embora historicamente a sociedade brasileira tenha sido construída com o recurso constante à violência, esta tem sido sistematicamente negada a nível ideológico. Ao contrário de países, como os Estados Unidos, onde a violência é considerada um traço tão nacional como o beisebol, no Brasil haveria uma índole pacífica supostamente herdada do português, que teria sabido tão gostosamente promover uma suave mistura de raças, criando aqui nos tópicos uma sociedade harmônica.

Bem diferente é o que nos ensina a nossa história. Nela vemos ocorrer, ao lado dos grandes e incruentos acontecimentos oficiais (como a Proclamação da Independência e a da República), a violenta repressão a movimentos populares como o Quilombo dos Palmares, a Cabanada, a Balaiada, Canudos, Contestado, os Muckers e a revolta da Chibata, a última resolvida de um modo tão brasileiro, isto é, a anistia dos rebeldes e seu subsequente desaparecimento. O uso da força também permeou acontecimentos nos quais o Estado não esteve diretamente envolvido, como as guerras civis no Rio Grande do Sul (onde o modo de tratar os inimigos era a degola), ou a vida cotidiana dos homens livres na ordem escravocrata cujo dia-a-dia era profundamente marcado pela violência ${ }^{1}$.

\footnotetext{
* Texto apresentado na mesa-redonda "Violência na Cidade" realizada em julho de 1980, no Rio de Janeiro, na 321 Reunião Anual da Sociedade Brasileira para o Progresso da Ciência e originalmente publicado em Dados — Revista de Ciências Sociais, 23 (3), 1980.

${ }^{1}$ Ver Franco, Maria Sylvia de Carvalho. Homens livres na ordem escravocrata. São Paulo, Ática, 1974.
}

Com a formação de uma força de trabalho urbana livre, o recurso à violência se torna uma constante. Durante toda a história da República o aparelho estatal brasileiro submeteu as classes dominadas a maus tratos e torturas. Na República Velha, os operários foram sempre encarados como potencialmente perigosos, devendo os líderes que procuravam organizá-los serem desterrados para lugares longínquos do Brasil ou, no caso de serem estrangeiros, deportados para seu país de origem, a fim de não contaminarem seus colegas ${ }^{2}$.

É neste momento que a questão social passa a ser considerada um caso de polícia e se criam inúmeros mecanismos de intimidação e controle que perduram até hoje, dos quais o mais bizarro talvez seja o fato de que, num país que sabidamente não consegue oferecer emprego a toda população em idade de trabalhar, um indivíduo possa ser detido sob a acusação de vadiagem por não portar carteira de trabalho assinada. Em outras palavras: em vez de combater o desemprego, o Estado combate o desempregado.

Em verdade, a violência e a tortura com que a polícia tem tradicionalmente tratado as classes populares, longe de se constituírem numa "distorção" devido ao "despreparo" do aparelho de repressão, "têm uma função eminentemente política — no sentido de contribuir para preservar a hegemonia das classes dominantes e assegurar a participação ilusória das classes médias nos ganhos da organização política baseada nessa repressão. O exercício continuado dessa repressão ilegítima consolida as imagens de segurança de status social das classes médias diante da permanente 'ameaça' que constitui para elas qualquer ampliação das pautas de participação popular",3.

O mito da índole pacífica do brasileiro conseguiu se desenvolver apesar destas evidentes manifestações de violência no cotidiano brasileiro e só foi extirpado depois de 1964 quando a repressão política também atingiu a classe média através da ação dos órgãos de segurança. Mas, mesmo no auge da repressão, o Estado preocupavase em divulgar uma imagem do Brasil como sendo uma ilha de

\footnotetext{
${ }^{2}$ Ver Pinheiro, Paulo Sérgio. Violência do Estado e classes populares. Dados (22), 1979. ${ }^{3}$ Ibid., p. 5.
} 
tranquilidade num mundo conturbado. O Brasil era "um país que ia para frente" e tratava-se de "amá-lo ou deixá-lo" como a AERP (Assessoria Especial de Relações Públicas do Governo Médici) se encarregava de nos doutrinar.

É por isto que chama a atenção o fato de que quando começa a "abertura" o mito da índole pacífica do brasileiro é relegado a um segundo plano no discurso oficial e a "violência urbana" é alçada à posição de "problema nacional", aparentemente por terem as classes média e alta sido também atingidas por ela. Entretanto, quando os meios de comunicação de massa e alguns políticos falam em "violência urbana" estão se referindo quase que exclusivamente à delinquência de classe baixa, minimizando o arbítrio policial e omitindo que, na realidade, são os acidentes de trabalho, a desnutrição e a miséria que vitimam um número muito maior de habitantes de nossas grandes cidades.

Se considerarmos que certos temas passam a se constituir em questões válidas em determinados contextos sociais, é importante perguntar por que a "violência urbana" passou a ser considerada um problema justamente quando o regime começou a entrar em crise e preocupou-se em promover um reordenamento pelo ato que foi batizado com o nome de abertura.

Para responder esta questão, a primeira constatação da qual se precisa partir é a de que não existem dados fidedignos sobre violência no Brasil. Isto se dá por dois motivos: o primeiro é que até agora não interessava ao regime, que estava construindo um "milagre econômico", chamar a atenção para suas contradições internas. Seria inconveniente, por exemplo, que se noticiasse uma correlação positiva entre o crescimento do produto nacional bruto e as taxas de criminalidade, fenômeno semelhante ao ocorrido na década de setenta em relação ao aumento da taxa de mortalidade infantil na cidade de São Paulo, o centro industrial do "milagre". O segundo motivo tem a ver com o fato de estatísticas sobre violência serem produzidas com base em informações da polícia que define criminalidade e violência com critérios próprios que frequentemente levam em consideração seu interesse em maximizar a ocorrência de certos tipos de comportamento, fenômeno que também ocorre em regimes liberais e democráticos ${ }^{4}$.

Entretanto, apesar da inexistência de estatísticas confiáveis sobre a violência no Brasil parece ser válido sugerir, partindo de informações e dados assistemáticos, que ela cresceu desde 1964. O seu aumento, porém, se deu tanto na cidade como no campo e tem menos a ver com o contexto no qual se manifesta e mais com as condições que lhe dão origem. Por isto é que cabe falar em violência na cidade e não em violência urbana. Utilizar o termo violência urbana — rótulo com o qual somos bombardeados recentemente - significaria aceitar o embuste de que existe uma violência que é inerente à cidade, qualquer que esta seja. Nesta perspectiva ideológica, o problema não seria brasileiro, mas universal. As causas do fenômeno, nesta visão, não seriam sociais mas essencialmente ecológicas, já que se imputa ao meio ambiente chamado de cidade a capacidade per se de gerar violência. Por isto, optar pelo termo violência na cidade implica em preservar a ideia de que a violência tem raízes sociais, manifestandose em contextos diferentes que não podem, entretanto, ser considerados como seus causadores.

As causas do aumento da violência no Brasil, a partir de 1964, parecem ser claras; o regime que tomou o poder sentiu necessidade de aumentar a violência institucional para alcançar seus objetivos: acelerar a acumulação de capital em associação com os interesses estrangeiros e efetuar uma modernização conservadora. Para isto foi necessário extinguir a estabilidade no emprego, promover o arrocho salarial e baixar uma legislação de exceção. Estas medidas só seriam possíveis desmantelando as antigas lideranças sindicais populistas e criando a ideologia do binômio "segurança e desenvolvimento", ou seja, repressão e acumulação de capital.

Isto se refletiu na cidade e no campo. Por esta razão, é importante assinalar que, apesar de inúmeros conflitos que ocorrem no meio rural, no qual índios e posseiros são vítimas da penetração do capital na agricultura, esta situação não é considerada uma questão legítima

${ }^{4}$ Ver, em relação ao suposto aumento de assaltos de rua na Grã-Bretanha, Hall Stuart; Critcher, Chas; Jefferson, John \& Roberts, Brian. Policing the crisis: mugging, the State, and law and order. Londres, MacMillan, 1978. 
e importante. Neste sentido, seria altamente fantástico que um programa como o Fantástico começasse a tratar da violência no campo no Brasil.

O aumento da violência no Brasil, a partir de 1964, começa por via institucional. Quando o Presidente Figueiredo, respondendo a uma pergunta de uma criança, afirmou que, se seu pai ganhasse o salário mínimo, meteria uma bala na cabeça, ele não estava fazendo mais do que reconhecer o que todo mundo já sabe: que o salário mínimo é uma incrível forma de violência.

$\mathrm{O}$ aumento de assaltos e roubos que se tem verificado nas grandes cidades brasileiras precisa, pois, ser discutido neste contexto. Por se constituírem nos centros mais dinâmicos do capitalismo no Brasil, suas grandes cidades representam espaços nos quais suas contradições se tornam mais evidentes, a riqueza e a opulência vivendo lado a lado com a mais flagrante miséria.

Não se trata, entretanto, de encampar o mito dos migrantes que, sendo expulsos do campo, vêm para a cidade e não tendo condições de se integrar à economia urbana, se voltam a formas violentas de ação. O que a realidade mostra é que, embora o capitalismo brasileiro tenha demonstrado uma natureza bem dinâmica, ele não é capaz de incorporar ao sistema produtivo toda a população em idade de trabalho. Esta massa de desempregados e subempregados vem a formar a maior parte do assim chamado setor informal da economia urbana e existem evidências sugerindo que ele não é composto somente por recém-chegados à cidade mas também por indivíduos há muito tempo marginalizados em relação ao processo produtivo e sua subsequente geração ${ }^{5}$.

Portanto, assim como a violência se constitui em mecanismo de dominação por parte das classes dominantes, ela se transforma cada vez mais numa estratégia de sobrevivência por parte das classes dominadas. Entretanto, a violência, neste contexto, não é praticada

\footnotetext{
5 Ver Yap, Lorene. Internal migration and economic development in Brazil. Tese de
doutorado, Harvard University, 1972; Costa, Manuel Augusto. Urbanização e migração

5 Ver Yap, Lorene. Internal migration and economic development in Brazil. Tese de
doutorado, Harvard University, 1972; Costa, Manuel Augusto. Urbanização e migração urbana no Brasil. Rio de Janeiro, IPEA/INPES, 1975 e Lodder, Celsius A. Distribuição de renda nas áreas metropolitanas. Rio de Janeiro, IPEA/INPES, 1976.
}

apenas para satisfazer necessidades econômicas, mas se reveste também de um caráter político já que também pretende, por parte de elementos das classes dominadas, recuperar parte do excedente daqueles por quem foram expropriadas.

Neste sentido, é revelador que, no Brasil, o termo marginal se refira simultaneamente à mão-de-obra não integrada ao processo de produção capitalista e a criminosos da classe baixa, aludindo à famosa distinção entre "classes trabalhadoras" e "classes perigosas"6.

Talvez tenha sido Rubem Fonseca quem melhor retratou o aspecto de ressarcimento e o desejo de compensar a privação de que se reveste a criminalidade de classe baixa no Brasil. Seu conto "Feliz Ano Novo" constitui uma brilhante análise da distância e do conflito entre estes "dois mundos" das grandes cidades brasileiras, cujos membros se encontram através de um assalto praticado por "marginais" no réveillon num bairro de classe alta do Rio de Janeiro. Não surpreende que o livro de Rubem Fonseca, que contém estes e outros contos, tenha ficado proibido por tantos anos pela censura brasileira.

No conto "O Cobrador", que dá título a uma obra sua mais recente, o personagem central é um "marginal" do Rio de Janeiro que acredita ter como missão cobrar a bala o que julga que a sociedade lhe deve: "Tão me devendo colégio, namorada, aparelho de som, respeito, sanduíche de mortadela no botequim da rua Vieira Fazenda, sorvete, bola de futebol. (...) Estão me devendo xarope, meia, cinema, filé mignon e buceta. (...) Estão me devendo uma garota de vinte anos, cheia de dentes e perfume". O cobrador conclui: "Sempre tive uma missão e não sabia. Agora sei. (...) Sei que se todo fodido fizesse como eu o mundo seria melhor e mais justo",

É, entretanto, fundamental perguntar a que propósitos serve a dramatização da violência. Procurando elaborar uma economia política da violência no Brasil atual, Aguiar Barros argumenta que

${ }^{6}$ Ver Chevalier, Louis. Classes laborieuses et classes dangereuses à Paris, pendant la première moitié du XlXe siècle. Paris, Librarie Générale Française, 1978.

Fonseca, Rubem. Feliz ano novo. Rio de Janeiro, Artenova, 1975.

${ }^{8}$ Id. $O$ cobrador. Rio de Janeiro, Nova Fronteira, 1979, p. 168, 174, 176 e 181. 
não "é suficiente mostrar a conexão entre violência e crime, com a sociedade de classes e a apropriação privada daquilo que é socialmente produzido. É preciso ir mais longe. É preciso mostrar como as classes dominantes se aproveitam (através das mediações político-ideológicas) deste drama social (decorrente da própria natureza do sistema capitalista) em benefício próprio, isto é, em benefício da reprodução desse mesmo sistema gerador da criminalidade, mas garantidor de seus privilégios e hegemonia" .

De fato a violência é alçada ao status de "questão nacional" entre nós, quando o modelo econômico entra em crise e torna-se difícil continuar lançando mão do discurso da segurança nacional porque não existe mais a ameaça da guerrilha. Com o recrudescimento da inflação, do desemprego e da crise política é preciso criar um novo bode expiatório. Este é o "marginal", figura que é utilizada para exorcizar os fantasmas de nossa classe média, tão assustada com a perda de seu status, com a sua crescente proletarização e com a queda de seu poder aquisitivo, alcançado nos anos do "milagre". É preciso tranquilizá-la e exconjurar seus demônios como se fazia na Idade Média queimando bruxas. Neste sentido, a ênfase que programas como o Fantástico emprestam à violência na cidade e o bombardeamento constante por parte dos meios de comunicação e dos políticos do regime a respeito da necessidade de um maior policiamento visam criar um clima de tensão permanente que, "longe de ameaçar o sistema, o consolida" ${ }^{10}$.

Neste esquema de utilização político-ideológica da violência nunca se questiona o controle sobre o aparelho de repressão, os crimes de colarinho branco, as grandes negociatas, os acidentes provocados por falta de segurança no trabalho e a morte pela miséria. Todas estas questões são relegadas a um segundo plano, já que se eleva à posição de "problema nacional" a violência em nossas grandes cidades.

Com este procedimento cria-se uma imagem maniqueísta da realidade; haveria sempre duas cidades em qualquer centro urbano brasileiro: uma dos "homens de bem" (coincidentemente possuidores

${ }^{9}$ Aguiar Barros, J. M. de. A utilização político-ideológica da delinquência. Encontros com a Civilização Brasileira (20): 12, 1980.

${ }^{10}$ Ibid., p. 13 . de bens) e outra dos "homens de mal" (coincidentemente nãopossuidores de bens). Esta visão dualista escamoteia o fato de que as "duas cidades" são, na verdade, um conjunto articulado, já que uma assegura a existência e reprodução da outra. A utilização desta imagem ideológica serve para aliviar a culpa que as camadas privilegiadas sentem, necessitando, portanto, que alguém transforme em ameaça constante e bode expiatório aqueles que não têm como participar do banquete. Em suma, uma situação já descrita naquele samba que fala de um tumulto numa gafieira: "Quem tá de fora não entra, quem tá de dentro não sai”. 


\section{Capítulo II}

\section{AS VÍTIMAS DA VIOLÊNCIA NO BRASIL*}

A violência urbana foi transformada no grande tema do Brasil nos últimos tempos. Basta abrir um jornal ou assistir a um noticiário de televisão para ser bombardeado com informações sobre as mais recentes vítimas de assaltos e crimes. É, portanto, natural que o tema renda IBOPE e ajude a vender jornais; é compreensível também que as mais variadas soluções sejam apontadas e apresentadas às autoridades competentes e ao público em geral: a pena de morte, o aumento do policiamento ostensivo, a prisão cautelar, a utilização das forças armadas na repressão ao crime, etc. E é natural também que tentativas sérias de reflexão sobre a violência sejam frequentemente rotuladas de academicismo típico de cientista social desocupado, incapaz de propor medidas imediatas para problemas urgentes.

O tema de violência em nossas cidades não é, entretanto, novo. Há um século atrás, Angelo Agostini, italiano radicado no Rio de Janeiro, publicava na Revista Ilustrada caricaturas nas quais satirizava os assaltos, a corrupção, a violência e a ineficiência da polícia carioca ${ }^{1}$.

Convém também recordar o célebre Major Vidigal, personagem do livro Memórias de um Sargento de Milícias de Manuel Antônio de Almeida, que retrata bem o arbítrio da polícia carioca já no começo do século passado. E nunca é demais lembrar que a primeira música a

\footnotetext{
* Texto apresentado na sessão sobre violência urbana do Seminário sobre Estudos Urbanos do Instituto Universitário de Pesquisas do Rio de Janeiro em março de 1981 e no simpósio "Violência e Cidade" realizado em julho de 1981, em Salvador, na 33" Reunião Anual da Sociedade Brasileira para o Progresso da Ciência. Publicado originalmente em 1982, pela Editora Zahar, na coletânea Violência e Cidade, e aqui reproduzido com sua autorização.

${ }^{1}$ Ver Cotrim, Álvaro (Álvarus). Caricatura. Uma arma contra os assaltos no Rio, há um século. Jornal do Brasil, 18 jan. 1981, Caderno B, p. 2.
}

ser gravada com o nome de samba, o famoso Pelo Telefone (de 1917), satiriza justamente as tradicionais ligações entre a polícia e o jogo.

É também notória a brutalidade que o aparelho estatal brasileiro tradicionalmente dispensa às classes populares, submetendo-as a maus tratos e torturas. Esta violência, que na República Velha era justificada pela ótica de que a questão social era um caso de polícia, tem sido uma constante em nossa história e, longe de ser uma "distorção" devido ao "despreparo" do aparelho repressivo, desempenha um papel essencialmente político, ajudando a manter o poder das classes dominantes ${ }^{2}$.

Dado o clima generalizado de insegurança e pânico que se apossou dos habitantes de nossas cidades, negar a existência ou o aumento da violência seria, no mínimo, uma insensatez. Mas, em vez de cair na armadilha fácil de elaboração de "propostas concretas e imediatas", a obrigação do cientista social é procurar analisar o que há de subjacente ao fenômeno. Por isso, é fundamental indagar o porquê do realce que a violência urbana tem recebido ultimamente e, portanto, se ela de fato é o maior problema que aflige a sociedade brasileira.

Existem temas que são considerados questões válidas no Brasil como a violência urbana - e temas que não o são, como a violência no meio rural, ligada aos conflitos em torno da posse da terra, à situação dos índios e à não-demarcação de suas terras, à morte pela fome e desnutrição, aos acidentes de trabalho, aos acidentes de trânsito, à corrupção, à violência policial, às relações entre a polícia, ao jogo e à política, etc.

Em verdade, o termo "violência urbana" refere-se quase que somente à delinquência de classe baixa, que no Rio de Janeiro deixou de estar restrita a áreas como a Baixada Fluminense para atingir os redutos das classes médias e altas como a zona sul.

Chama a atenção o fato de que a ascensão do tema de "violência urbana" à categoria de "problema nacional" coincida com o que se

\footnotetext{
${ }^{2}$ Ver Pinheiro, Paulo Sérgio. Violência do Estado e classes populares. Dados (22), 1979.
} 
convencionou chamar de "abertura" política. Significaria isto que anteriormente os índices de violência não eram elevados?

Apesar da ausência de estatísticas confiáveis, é de se supor que a violência cresceu no Brasil desde 1964, tanto na cidade como no campo. Esta violência aumentou por via institucional e é bem simbolizada pelo binômio "segurança e desenvolvimento". Para acelerar a acumulação de capital e efetuar uma modernização conservadora, o regime que tomou o poder em 1964 desmantelou as antigas lideranças sindicais populistas, extinguiu a estabilidade no emprego, promoveu o arrocho salarial, criou uma legislação de exceção e se valeu do recurso constante ao arbítrio.

Mas até há pouco não era conveniente a um regime que dirigia os destinos de um "país que ia para a frente" admitir a existência da violência e, por conseguinte, de indivíduos insatisfeitos ou impacientes, que estavam tentando repartir o bolo, a seu modo, antes de ele ter crescido suficientemente. O Brasil era até recentemente apresentado como uma ilha de tranquilidade num mundo conturbado. A única nota destoante era a "subversão da ordem", inimiga que era vista exigindo um combate sem tréguas, em nome do qual se montou um vasto aparelho de repressão. Esse aparelho, que teve um crescimento vertiginoso, inclui as polícias militares que, a partir de 1967, passaram a ser consideradas forças auxiliares, reservas do Exército, cabendo-lhes a manutenção da ordem pública e da segurança interna das unidades federadas, ficando subordinadas à Inspetoria Geral das Polícias Militares do Ministério do Exército.

Com o início da "abertura", o tema da violência foi promovido ao principal problema nacional, recebendo mais destaque inclusive que os índices inflacionários. A violência urbana é, pois, alçada ao status de "questão nacional" justamente quando o modelo econômico e político entra em crise e perde sentido recorrer ao discurso da segurança nacional, já que desapareceu o perigo da guerrilha.

O que está havendo, na verdade, no Brasil, é uma dramatização da violência, através da qual se constrói uma imagem maniqueísta da sociedade: existiriam os "homens de bem" e os "homens de mal". Cria-se, assim, um novo bode expiatório, o "marginal", figura que serve para exorcizar os fantasmas de nossa classe média cada dia mais assustada com a inflação, o desemprego, a perda de seu status, a sua crescente proletarização e a queda de seu poder aquisitivo alcançado nos anos do "milagre"”.

Mas é de uma violência muito específica de que se fala. Do modo como as coisas são apresentadas, trata-se de uma violência que é chamada de "urbana". O rótulo é importante, pois sugere que existe uma violência que é inerente à cidade, qualquer que esta seja. $\mathrm{O}$ problema, portanto, não seria brasileiro, mas mundial e suas causas não seriam sociais, mas ecológicas, já que se imputa ao meio ambiente chamado de cidade a capacidade per se de gerar violência. Em última análise, estar experimentando um aumento de criminalidade em nossas grandes cidades seria pagar o preço do ingresso na modernidade, simbolizada pelas metrópoles, desfrutando assim a honrosa companhia de cidades grandes e violentas como Nova Iorque.

A cidade, obviamente, não é a causa per se da violência, e por isto talvez devêssemos falar em violência na cidade em vez de violência urbana, já que este último termo implica aceitar que existe uma violência que é especifica da cidade, quando, na verdade, esta é apenas o contexto no qual a violência se manifesta.

Especificamente, no Brasil, as grandes cidades, por se constituírem nos centros mais dinâmicos de sua economia, representam espaços nos quais suas contradições se tornam mais evidentes, a riqueza e a opulência convivendo com a mais flagrante miséria. Este contraste entre ostentação e indigência poderia ser encarado como o elemento que fornece a base necessária ao surgimento da delinquência de classe baixa.

Procurando enxergar a violência do ângulo do delinquente de classe baixa - o assaltante, o trombadinha - poder-se-ia encará-la como uma estratégia de sobrevivência num contexto onde as desigualdades sociais são gritantes. Neste contexto, a possibilidade de conseguir empregos regulares é escassa, a remuneração do trabalho nãoqualificado é extremamente baixa e boa parte da população urbana sobrevive no setor informal, desempenhando atividades chamadas de

\footnotetext{
${ }^{3}$ Ver, neste sentido, o capítulo I deste livro.
} 
marginais. Poder-se-ia, portanto, argumentar que nestas condições a violência não é praticada somente para satisfazer necessidades econômicas, mas possui igualmente uma conotação política, pois também tem como meta, do ponto de vista do delinquente, recuperar parte do excedente de que foram expropriadas as classes subalternas. Neste sentido, é significativo que, no Brasil, o termo "marginal" se refira, ao mesmo tempo, à mão-de-obra não inserida em relações capitalistas de produção e a criminosos de classe baixa.

Isto não nos deve, naturalmente, fazer cair no engodo de imputar mecanicamente a criminalidade à pobreza. Embora a falta de oportunidades de trabalho com remuneração condigna possa levar à criminalidade, não são obviamente todos os pobres que se valem da delinquência para sobreviver.

É, pois, preciso distinguir entre diferentes formas de violência existentes no Brasil. Ao que tudo indica, o trânsito matou mais que os assaltos no Rio de Janeiro em $1980^{4}$.

Entretanto, os acidentes de trânsito não são considerados um "problema nacional". O mesmo, provavelmente, poderia ser afirmado dos acidentes de trabalho, dos quais o Brasil é um dos recordistas mundiais. Isto para não citar as mortes causadas pela desnutrição e pela miséria.

Também não entram na categoria de violência os grandes acidentes causados pela falta de controle e pela impunidade com que são tratados seus responsáveis, como os incêndios em edifícios ou os naufrágios de barcos de transporte público que, ao excederem sua capacidade de carga, vitimam num dia centenas de pessoas. E o que dizer da delinquência financeira representada pela corrupção, as grandes negociatas e os "estouros" que vêm se repetindo nos últimos anos e cujos prejuízos acabam geralmente sendo socializados pela nação? Os duzentos e poucos assaltos a banco efetuados em 1980 no Brasil renderam a seus autores menos de 300 milhões de cruzeiros, quantia vinte vezes inferior à obtida pelos golpes no mercado

${ }^{4}$ VEJA. O Rio ferido a bala (644): 16, 7 jan. 1981. financeiro no período de dois meses que vai do final de novembro de 1980 ao final de janeiro de $1981^{5}$.

No Brasil, os prejuízos da delinquência financeira não só são muito superiores aos dos assaltantes mas também os efeitos da violência policial tendem a superar os efeitos da criminalidade das classes subalternas. De fato, nos mais recentes sequestros e assassinatos ligados ao jogo do bicho e ao tráfico de tóxicos encontram-se, quase sempre, indivíduos ou quadrilhas organizadas com a ajuda ou proteção de policiais ou ex-policiais. Fica, assim, muito difícil distinguir a fronteira entre a polícia e o criminoso.

Na verdade, as classes dominadas são, frequentemente, muito mais as vítimas que os autores de violência em nossas cidades. A impunidade com que são tratados os policiais que praticam arbitrariedades ou matam "no exercício da função" 6 faz com que a polícia seja tão ou mais temida que os delinquentes, por parte das classes populares. $\mathrm{O}$ grau de descrédito com que é encarada a polícia e a possibilidade de se obter justiça no Brasil é evidenciado pela sucessão de linchamentos que se têm verificado ultimamente.

O clima de insegurança e violência em que vivem nossas populações urbanas é um reflexo do capitalismo selvagem que caracteriza o atual modelo de desenvolvimento brasileiro, o qual, ao exacerbar as desigualdades sociais, valeu-se crescentemente do arbítrio. Esse modelo fortaleceu um aparelho de repressão que avoca a si a função judicial de decidir quem é culpado e quem é inocente, prendendo, torturando e matando em nome da segurança pública.

Por isto o tema da violência no Brasil passa obrigatoriamente pela discussão da democracia. Embora não haja uma relação mecânica entre arbítrio e criminalidade ou entre democracia e não-violência, enquanto não houver um real estado de direito e uma efetiva

\footnotetext{
${ }^{5}$ VEJA. Um mercado ameaçado (648): 60, 4 fev. 1981.

${ }^{6}$ Em 1980 os policiais da ROTA (Rondas Ostensivas Tobias de Aguiar) mataram 150 pessoas na Grande São Paulo. No primeiro semestre de 1981 o número de mortos foi de 124. Ver A ROTA está mais eficiente neste ano. Isto É (217): 24-5, 18 fev. 1981 e Pinheiro, Paulo Sérgio. Mais que na África do Sul. Isto É (249): 37, 30 set. 1981.

${ }^{7}$ Ver Benevides, Maria Victória. Mata! Esfola! Lincha! Jornal do Brasil, 22 março 1981, Caderno Especial, p. 4-5.
} 
participação da população nas decisões que afetam a sua vida, estaremos todos sujeitos a cair numa situação semelhante à descrita por Machado de Assis em $O$ Alienista. Aí, só nos restará gritar: "chame o ladrão!"

\section{SEGUNDA PARTE}




\section{Capítulo III}

\section{A MALANDRAGEM NA MÚSICA POPULAR BRASILEIRA*}

Ensinam algumas obras de economia política que, numa sociedade na qual o modo de produção capitalista é hegemônico, é a oposição entre os dois principais agentes da produção - o capital e o trabalho - que se sobrepõe a todas as demais. Em outras palavras, existiriam duas classes antagônicas: a burguesia que detém os meios de produção, e o proletariado, que tem apenas sua força de trabalho para vender. É a isto que se refere, em parte, o direito à liberdade da ideologia burguesa: liberdade de vender sua capacidade de trabalho e liberdade de alguém comprá-la, podendo, por conseguinte, acumular capital. Bastante diferente, portanto, do feudalismo.

Mas no Brasil não houve feudalismo e, portanto, nossa burguesia não é igual à européia: não teve que lutar contra a aristocracia feudal, nem que fazer sua revolução (apesar do que pensavam alguns autores em relação à pretensa conotação burguesa da revolução de 1930).

Na verdade, como mostrou Schwarz, a ideologia liberal oriunda da Europa sofria uma curiosa transfiguração no Brasil do século passado antes da abolição da escravatura. Aqui, as ideias estariam "fora do lugar" já que a noção burguesa de direitos convivia e era ofuscada pela prática do favor que "é a nossa mediação quase universal".

Isto era compreensível numa sociedade em que a mão-de-obra era escrava, os latifundiários estavam vinculados (no nível da circulação das mercadorias que eram exportadas) com o capitalismo mundial, e os homens livres, apesar de se perceberem como iguais, dependiam do favor como mecanismo de sobrevivência.

* Este texto é dedicado a: Klaus e Seldi, que me iniciaram nesta e noutras transas; Cafeco, o último malandro da Urca, e Águas, sua musa.

${ }^{1}$ Schwarz, Roberto. As ideias fora do lugar, in: - . Ao vencedor as batatas. São Paulo, Duas Cidades, 1977, p. 16
Embora a instituição do favor e do clientelismo continue existindo até nossos dias, tudo isto ocorreu antes que houvesse uma efetiva industrialização no Brasil, que só se iniciou no fim do século passado e que se desenvolveu mais substancialmente depois da crise mundial do capitalismo a partir de 1929. No fim do século passado e primeiras décadas deste, a mão-de-obra desta incipiente industrialização era, em boa parte, de origem européia, com uma militante liderança anarquista. Isto não chegava a se constituir numa ameaça "política" já que o proletariado era numericamente pequeno e a questão social podia ainda ser tratada como um caso de polícia.

É na década de trinta, quando a industrialização se intensifica, que a questão social deixa de ser um caso de polícia e passa a ser uma questão de Estado, que, saindo de uma crise política, utiliza a massa que migra do campo para a cidade como uma força legitimadora. Entra em cena o personagem povo e o populismo.

Traçando novamente um paralelo entre o que tinha ocorrido na Europa e o que vinha ocorrendo no Brasil, é bom relembrar que no Velho Mundo o proletariado passou por longas lutas e foi aos poucos arrancando concessões que encurtaram sua jornada de trabalho, elevaram seus salários, melhoraram suas condições de vida e garantiram maiores direitos políticos. A greve e o sindicato foram dois instrumentos-chave nestes processos.

Já no Brasil, o processo se deu de modo muito diferente. A legislação trabalhista criada por Vargas, na medida em que se antecipou às reivindicações dos trabalhadores e lhes concedeu vantagens e direitos pelos quais a classe operária como um todo ainda não tinha lutado, criou uma estrutura sindical atrelada ao Ministério do Trabalho, que funcionou como um poderoso e eficiente mecanismo de controle, impossibilitando a organização a nível horizontal entre trabalhadores. Isto, em última análise, reedita, no contexto urbano-industrial, o padrão do paternalismo e do clientelismo no qual mais vale procurar favores do patrão do que se unir e se organizar com seus iguais. É fácil perceber como o favor continua existindo.

Embora tenha sido a partir desta época que se desenvolve um governo mais centralizado que procura dar a impressão de estar apoiado numa burocracia racional, o aparelho estatal é utilizado de 
modo essencialmente clientelístico, assegurando poder político em troca de cargos burocráticos e favores.

A lógica da continuidade do clientelismo nas áreas urbano-industriais do Brasil reside no fato de que aqui não se desenvolve uma separação radical entre interesses agrários e industriais e que também, apesar de seu dinamismo, o capitalismo brasileiro não é capaz de incorporar ao sistema produtivo toda população urbana em idade de trabalho.

Neste processo de aclimatação do favor ao contexto urbanoindustrial, o jeitinho, o galho-quebrado, o pistolão, a panelinha e a malandragem são instituições fundamentais. Todas estas práticas implicam, de diferentes formas, a burla da perspectiva universalista contida na ideologia burguesa. Elas significam que a lei é feita para os inimigos e o trabalho para o otário.

É justamente como rejeição do trabalho e como estratégia de sobrevivência que a malandragem precisa ser compreendida. Neste sentido, cabe relembrar o quanto o trabalho manual no Brasil tem sido historicamente considerado uma atividade não-dignificadora, algo reservado somente para os escravos. Daí a expressão "trabalho para negro" ou mourejar (de mouro) aplicada ao trabalho físico que exige esforço ${ }^{2}$. É lógico que o "horror ao batente" não desapareceu com o fim da escravidão e continuou existindo no começo deste século, já que as condições do homem que trabalhava continuavam sendo extremamente opressivas.

Como se sabe, o fim da escravidão no Brasil não significou o surgimento de uma sociedade mais aberta, mas a continuidade do padrão de dominação oligárquica. Mesmo com a intensificação da industrialização, o trabalho assalariado não se tornou uma forma de qualificação, pois a ordem social continua sendo fortemente excludente. Assim, a malandragem, ao recusar o trabalho assalariado, se configura numa alternativa - transformada em estratégia de sobrevivência - numa sociedade que marginaliza o trabalhador, não

${ }^{2}$ A respeito das raízes históricas da repulsa ao trabalho manual do Brasil ver Buarque de Hollanda, Sérgio. Raízes do Brasil. Rio de Janeiro, José Olympio, 1936 e Moog, Vianna. Bandeirantes e Pioneiros. Rio de Janeiro, Civilização Brasileira, 1966.
The assegurando condições de viver decentemente do fruto de seu labor.

Por isto é importante registrar que o tema da malandragem se desenvolve mais intensamente na música popular brasileira nas décadas de 1920, 30 e 40. Ao voltar da Europa em 1933, Oswald de Andrade teve fina perspicácia ao afirmar que, no Brasil, o contrário do burguês não era o proletário, mas o boêmio. Ironia à parte, ele captou um aspecto essencial da ideologia da cultura brasileira por ocasião do desenvolvimento da industrialização. Assim como no século passado não havia lugar para o exercício de direitos, operando-se, portanto, principalmente com a categoria do favor, no começo do século atual não havia ainda espaço - salvo entre os militantes anarquistas - para a ideia do conflito entre capital e trabalho, sequer a nível das representações simbólicas.

De acordo com Gilberto Vasconcellos, o fascínio pela malandragem na nossa música popular surge numa fase em que o conflito entre capital e trabalho ainda não recobria todo o espaço social no Brasil, havendo, portanto, uma brecha a ser ocupada pela metáfora da malandragem. Para o referido autor,

enquanto a maioria da população é obrigada a ingressar na produção e viver de um trabalho mais ou menos regular, submetendo-se às exigências da labuta em conformidade com o código ideológico dominante, o malandro - sublinha nosso cancioneiro popular parece ter um destino social mais brando, dando aqui e ali um jeitinho no aperto, através da sua irresistível picardia e da sua visagem sedutora. Embora seja a cama uma "folha de jornal"; o cortinado, um "vasto céu de anil"; o despertador, um "guarda civil", ele sempre arruma uma saída para a penúria, como sugerem Noel e Kid Pepe em O Orvalho vem caindo ${ }^{3}$.

Em um artigo clássico sobre o romance Memórias de um Sargento de Milícias, Antônio Cândido caracterizou a dialética da malandragem como uma dialética de ordem e desordem. Os personagens do livro de Manuel Antônio de Almeida pertencem a um setor intermediário e anômico da sociedade brasileira do começo do século passado: o dos

${ }^{3}$ Vasconcellos, Gilberto. Yes, nós temos malandro, in: Música popular: de olho na fresta. Rio de Janeiro, Graal, 1977, p. 104. 24 
homens livres que não sendo escravos nem senhores não podem prescindir da ordem nem viver dentro dela.

Ordem dificilmente imposta e mantida, cercada de todos os lados por uma desordem, vivaz, que antepunha vinte mancebias a cada casamento e mil uniões fortuitas a cada mancebia. Sociedade na qual uns poucos livres trabalhavam e os outros flauteavam ao Deus dará, colhendo as sobras do parasitismo, dos expedientes, das munificências da sorte ou do roubo miúdo. Suprimindo o escravo, Manuel Antônio suprimiu quase totalmente o trabalho; suprimindo as classes dirigentes, suprimiu os controles do mando. Ficou o ar de jogo dessa organização bruxuleante fissurada pela anomia, que se traduz na dança dos personagens entre lícito e ilícito, sem que possamos afinal dizer o que é um e o que é o outro, porque todos acabam circulando de um para outro com uma naturalidade que lembra o modo de formação das famílias, dos prestígios, das fortunas, das reputações, no Brasil urbano da primeira metade do século $19^{4}$

Segundo Antônio Cândido, a estrutura de Memórias de um Sargento de Milícias evidencia uma tensão de duas linhas. Certos aspectos do livro puxam para a experiência de um segmento social numa sociedade concreta e historicamente delimitada. Contudo, o cunho popular da obra introduz elementos arquetípicos, puxando para o lado folclórico e irreal, sem preocupações com a situação histórica particular.

De acordo com a primeira linha, o malandro é tipificado no romance de Manuel Antônio de Almeida como sendo de origem pequenoburguesa - gente livre e modesta - que vive no que atualmente seriam as áreas centrais do Rio de Janeiro, sem quase nunca trocá-las pelo subúrbio ou pelos arredores rurais da cidade.

Na perspectiva da segunda linha, as Memórias "exprimem a vasta acomodação geral que dissolve os extremos, tira o significado da lei e da ordem, manifesta a penetração recíproca dos grupos, das ideias, das atitudes mais díspares, criando uma espécie de terra-de-ninguém

${ }^{4}$ Cândido, Antônio. Dialética da malandragem. Revista do Instituto de Estudos Brasileiros (8): 32, 1970. A respeito deste artigo, ver Schwarz, Roberto. Pressupostos, salvo engano, da "Dialética da Malandragem". Ensaios de Opinião (13), 1979. moral, onde a transgressão é apenas um matiz na gama que vem da norma e vai ao crime" 5 .

Neste plano arquetípico, o livro aponta para um modo de ser brasileiro caracterizado pela percepção de um mundo sem culpabilidade que corresponde a uma visão muito tolerante e quase amena da vida. Assim, o malandro faz coisas que poderiam ser consideradas como reprováveis, mas faz também outras dignas de louvor, que as compensam. Como de tudo se depreende um ar de facilidade, uma visão folgada dos costumes, a repressão moral só pode existir fora das consciências individuais, constituindo-se em "questão de polícia".

Segundo Da Matta existem duas interpretações simultâneas, consideradas igualmente válidas, da realidade brasileira: de um lado, o mundo como algo manipulável, o "jeitinho", o "galho quebrado", a malandragem. De outro, o mundo do "caxias", mundo este percebido como algo "racional". Assinalando a simpatia com que o malandro é encarado no Brasil, este autor aponta que a ele é atribuída

uma capacidade sutil, audaciosa e, acima de tudo, inteligente de manipular todas as leis, regulamentos, fórmulas, portarias, regras e códigos em seu próprio benefício. Não é, pois, por mero acaso que a figura do malandro seja tão admirada e idealizada no Brasil. Estando a um passo da marginalidade e a outro da estrutura, o malandro é o paradigma do tipo brasileiro do homem que é capaz de 'vencer sem fazer força'. É o tipo que permanece na 'sombra e na água fresca', enquanto seus patrícios correm para cumprir e aplacar seus superiores diante de um novo decreto ${ }^{6}$.

Assinalando o aspecto urbano da malandragem, Berlink argumenta que

O descomprometimento com a vida do trabalho está implícito na ética da malandragem e o comprometimento com uma vida folgada, só podem ser produzidos pelas horas de ócio e pela especialização da vida urbana. No meio rural não há malandros. Lá, a esperteza e as

\footnotetext{
${ }^{5}$ Cândido, op. cit., p. 86-7.

${ }^{6}$ Da Matta, Roberto. O carnaval como um rito de passagem, in: - Ensaios de antropologia estrutural. Petrópolis, Vozes, 1973, p. 154. Ver também do mesmo autor Carnavais, malandros e heróis. Rio de Janeiro, Zahar 1979.
} 
ações folgazãs são atribuídas a animais como a raposa, o jabuti e o macaco. Lá o homem vive como passarinho. Acorda com o sol e dorme no momento em que o sol se põe. No meio rural não há cabarés; não existe a Lapa, o Cassino da Urca, o rádio, as gravadoras e os golpes de sorte e o jogo que garantem os recursos necessários à vida boêmia do malandro ${ }^{7}$.

A malandragem, na época de seu apogeu na música popular brasileira (a década de trinta), se constitui simultaneamente em estratégia de sobrevivência e concepção de mundo através das quais alguns segmentos das classes subalternas se recusam a aceitar a disciplina e a monotonia associadas ao universo do trabalho assalariado. Isto fica claro no samba $O$ que será de mim?, de 1931, composto por Ismael Silva, um autêntico cultor da malandragem:

$$
\begin{aligned}
& \text { Se eu precisar algum dia } \\
& \text { De ir pro batente } \\
& \text { Não sei o que será } \\
& \text { Pois vivo na malandragem } \\
& \text { E vida melhor não há } \\
& \text { Oi, não há vida melhor } \\
& \text { Que vida melhor não há } \\
& \text { Deixa falar quem quiser } \\
& \text { Deixa quem quiser falar } \\
& \text { O trabalho não é bom } \\
& \text { Ninguém pode duvidar } \\
& \text { Oi, trabalhar só obrigado } \\
& \text { Por gosto ninguém vai lá. }
\end{aligned}
$$

O horror ao trabalho, que é encarado como fonte de sofrimento ("Se eu precisar algum dia/ De ir pro batente/ Não sei o que será"), e a

\footnotetext{
${ }^{7}$ Berlinck, Manuel Tosta. Sossega leão: algumas considerações sobre o samba como forma de cultura popular. Contexto (1): 108, 1976.
}

exaltação da malandragem enquanto estilo de vida ("vida melhor não há”) ficam explícitas nesta composição e comparecem também no samba Nem é bom falar, de 1931, do mesmo Ismael Silva em parceria com Nílton Bastos, Francisco Alves e Noel Rosa, no qual os compositores alarmados temem que "Nem é bom falar/ Se a orgia acabar", garantindo entretanto que "esta vida/ Não há quem me faça deixar".

Uma constante das composições deste período é que "a vadiagem aparece ao compositor como a única alternativa possível de sobrevivência numa sociedade cuja estrutura social converte o homem que trabalha num marginal econômico, empobrecendo-o dia a dia" ${ }^{8}$. Isto comparece, por exemplo, no samba Caixa Econômica de Orestes Barbosa e Antônio Nássara gravado em 1933:

Você quer comprar o seu sossego

Me vendo morrer num emprego

Pra depois então gozar

Esta vida é muito cômica

Eu não sou Caixa Econômica

Que tem juros a ganhar

E você quer comprar o quê, hein?

Você diz que eu sou moleque

Porque não vou trabalhar

Eu não sou livro de cheque

Pra você ir descontar

Se você vive tranquila

Sempre fazendo chiquê

Sempre na primeira fila

Me fazendo de guichê

\footnotetext{
${ }^{8}$ Vasconcellos, op. cit., p. 107.
} 
E você quer comprar o quê, hein?

Meu avô morreu na luta

E meu pai, pobre coitado

Fatigou-se na labuta

Por isso eu nasci cansado

E pra falar com justiça

Eu declaro aos empregados

Ter em mim esta preguiça

Herança de antepassados.

O trabalho nesta composição é encarado como inútil para as classes subalternas ("Meu avô morreu na luta/ E meu pai, pobre coitado/ Fatigou-se na labuta") e, portanto, a preguiça transforma-se num traço hereditário que já se manifesta por ocasião do nascimento ("Por isso eu nasci cansado/ E pra falar com justiça/ Eu declaro aos empregados/ Ter em mim esta preguiça/ Herança de antepassados").

Neste samba a mulher comparece, por um lado, simbolizando o mundo da ordem e da estabilidade ("Você quer comprar o seu sossego/ Me vendo morrer num emprego") e, por outro, como predadora ("Eu não sou livro de cheque/ Pra você ir descontar") e consumista ("Sempre fazendo chiquê"), tema que será retomado na análise da letra de outras composições.

A falta de "vocação para o trabalho" também está presente em Felicidade, samba que René Bittencourt lançou em 1932 e no qual proclama: "O meu destino foi traçado no baralho/ Não fui feito pro trabalho/ Eu nasci pra batucar".

Como se percebe a malandragem se constitui num "destino". Mas enquanto, na versão weberiana ${ }^{9}$, a predestinação calvinista do homem daria origem a uma ética do trabalho, através da qual se enalteceria a obra de Deus e buscar-se-iam indícios de salvação, no Brasil a

${ }^{9}$ Ver Weber, Max. A ética protestante e o espírito do capitalismo. São Paulo, Pioneira, 1967. situação é diferente, já que Deus é brasileiro, não existindo pecado do lado de baixo do Equador e a "salvação" tropical não se dá pelo trabalho, mas através da ética da malandragem.

$\mathrm{Na}$ verdade, além do "horror ao batente", há uma série de temas que são recorrentes em músicas de malandragem. Para início de conversa, existe a crônica escassez de dinheiro. Malandro está sempre em estado de "prontidão" já que o miserê é grande. Neste sentido basta recordar composições conhecidas de Noel, nas quais a falta de dinheiro é uma constante, como Com que Roupa?, O Orvalho Vem Caindo e Fita Amarela. A letra desta última música deixa isto bem claro: "Não tenho herdeiros/ Nem possuo um só vintém/ Eu vivi devendo a todos/ Mas não paguei a ninguém".

Outro tema é a valentia. Malandro, que se preza, está sempre com a navalha no bolso e não foge de briga ${ }^{10}$. Mesmo no caso de Madame Satã, malandro é cabra macho e sabe impor respeito na base da força. Em Chang Lang, Moreira da Silva e Ribeiro Cunha conseguiram numa só composição reunir os temas da prontidão e da valentia.

Eu fui ao restaurante chinês

E peguei o gordurame sem ter o arame

E disse ao china: pra semana pagarei

O Chang Lang se queimou comigo sem ter razão

É na burindana disse: aqui não é pensão

Se você quer comer de graça, você tem que trabalhar

Ou deixa em depósito seu chapéu de palha

Vá-se embora, por favor, mas eu não sou seu pai

$\mathrm{Na}$ alta roda de malandros

Sempre fui considerado um batuqueiro respeitado

Me queimei com a ignorância do chinês

${ }^{10}$ É interessante lembrar que o tema da valentia também está presente no tango através da figura do "guapo". 
E disse: Chang, se aguenta, vá por mim que eu pagarei

Se eu me agarro com você

Derrubo todas as prateleiras

Tamismane quer dizer: quedê o dinheiro?

O velho Tempedrani

Eu estou na durindana

Eu pago a conta pra semana

Aguenta aí

Dificilmente o malandro perde o controle

Eu disse: está bem, vou pagar

Meti a mão lá na aduana

Mas em vez de grana puxei da minha navalha

Tomei o meu chapéu de palha pra poder me desviar

Mas Chang, o que é que há?

Está desconfiado de seu camarada?

Se eu me agarro com você

Derrubo todas as prateleiras

Tamismane quer dizer: quedê o dinheiro?

O velho Tempedrani

Eu estou na durindana

Eu pago a conta pra semana

Aguenta aí.

Além da "prontidão" e da valentia, esta composição reúne outros temas. Um deles é a esperteza, atributo que se constitui na capacidade de se desvencilhar de situações difíceis através da "lábia" e do "jogo de cintura", o que transparece em versos como "Chang, se aguenta, vá por mim que eu pagarei", "Eu pago a conta pra semana/ Aguenta aí", "Mas Chang, o que é que há?/ Está desconfiando de seu camarada?".

Outro tema que aparece com clareza é o que poderia se chamar de "categoria". Como diz um samba bem mais recente, "malandro que é malandro tem que ter categoria". Em Chang Lang, o narrador proclama o alto conceito que goza entre seus pares ("Na alta roda de malandros/ Sempre fui considerado um batuqueiro respeitado") e, diante da negativa do dono do restaurante em lhe fiar a refeição, resolve partir para a ação direta, mas na base da surpresa, já que sabe que uma das regras de conduta é que "dificilmente o malandro perde o controle". A solução é apelar para o "jogo de cintura": "Eu disse: está bem, vou pagar/ Meti a mão lá na aduana/ Mas em vez de grana puxei da minha navalha/ Tomei o meu chapéu de palha pra poder me desviar". Por via das dúvidas, o narrador continua até o final prometendo pagar a conta pra semana. É isto ai: bronca é arma de otário, já que malandro tem que ter categoria, valentia, lábia e jogo de cintura pra poder se safar cotidianamente da "prontidão".

O "golpe" é outro tema constante nas músicas de malandragem. Como, para que possa haver malandro, é preciso que também haja a figura do otário, é a este que geralmente cabe "pagar o pato". O tema do golpe é bem retratado, em Aviso aos Fazendeiros, de Lourival Ramos, Ribeiro Cunha e Moreira da Silva:

\section{Estava na Central}

Quando chegou o noturno do interior

Cheio de passageiros

Onde vinha um gajo de chapéu de aba larga

Cano de bota no estilo de fazendeiro

Mais do que depressa fui me aproximando

Acendi um cigarro e comecei a palestrar

Ele perguntou se eu podia dar um jeito

De arranjar um bom hotel para ele descansar

E foi logo dizendo que tinha um milhão 
E queria ir à tal Caixa Econômica guardar

Meto-lhe a conversa tomo-lhe a granalina

Entro no Campo Santana e mando o Jeca me esperar

Saio no portão do fundo apanho um carro e vou em frente

Desguio com o milhão sabendo que ele era rico

Pois ele deve de saber perfeitamente

Que o palhaço com dinheiro

Pode incendiar um circo

(Eu sou malandro e vivo disso é sirico tico).

Como se pode depreender do título, o otário, no caso, é o fazendeiro, representante de uma categoria social que estava sendo atingida pelas mudanças na economia acarretadas pela industrialização. Ele é retratado como o Jeca que não sabe se comportar diante da sofisticação da vida urbana e acaba, portanto, sendo presa fácil do malandro que justifica sua ação como um modo de sair do miserê graças ao golpe dado a uma pessoa a quem não falta dinheiro ("Desguio com o milhão sabendo que ele era rico").

O jogo e a sorte fornecem outro tema constante da malandragem, já que ambos se constituem em estratégias de sobrevivência que podem permitir a recusa do trabalho. Em Que Barbada de Walfrido Silva, Moreira da Silva e Jucata fica explícita a ligação entre a tentativa de sair da pobreza e o jogo:

Ó seu moço não empurre isto na vez

Já cansei de esperar

Quero comprar a pule três

Hoje tenho uma legitima barbada

Com certeza é a égua turquesa

Vou pra cabeça acertar com que placê

A grana vai ser boa

Vou sair do miserê
Mas se por acaso não acertar

Nem trocados para o bonde eu terei para voltar

Há muito tempo eu não acerto uma

Porque me dão informações erradas

E a grana toda que eu acumulei

Foi empatando nas acumuladas

Levei um banho domingo passado

Perdi tudo que eu tinha num cavalo bem cotado

Pulou na frente e atacou por fora

O maluco desgarrou e está correndo até agora.

O tema da aposta serve também para satirizar as tradicionais ligações entre a polícia e o jogo. Na verdade, este outro tema recorrente da música de malandragem - a crítica à corrupção e aos desmandos do poder - já comparece nos primeiros versos do célebre samba de Donga e Mauro de Almeida, Pelo Telefone, gravado em 1917, no qual se parodia o fato de que no Largo da Carioca no Rio de Janeiro jogava-se roleta em plena rua, sem que a polícia tomasse qualquer providência:

\section{O chefe da polícia \\ Pelo telefone \\ Mandou me avisar \\ Que com alegria \\ Não se questione \\ Para se brincar.}

Consta que ${ }^{11}$ estes primeiros versos também eram cantados assim:

\footnotetext{
${ }^{11}$ Ver Sodré, Muniz. Samba, o dono do corpo. Rio de Janeiro, Codecri, 1979, p. 54. É oportuno recordar que o Major Vidigal das Memórias de um Sargento de milícias, criado a partir de um personagem real, retrata bem o arbítrio e os desmandos da polícia carioca já no começo do século passado.
} 


\section{Que na Carioca}

Tem uma roleta

Pra se jogar.

As conhecidas ligações entre a polícia e o jogo do bicho são também satirizadas em Deu Bode... Pra Polícia de Silvino Netto:

"Seu" comissário me perdoe o rebolado

Mas eu desejo uma melhor explicação

Soube notícia que os jornais têm publicado

Onde alguém levou a parte do "Leão".

Pelo que eu vejo essa boca é muito boa...

E o tutu vai muito acima de um bilhão!

E eu lhe faço uma pergunta à-toa..

Qual foi o "tal" que afinal meteu a mão?

Joguei no touro, no macaco e no cavalo...

No elefante, no peru e no pavão!

De todo o jeito eu cerquei o galo...

E o resultado arrebentou na minha mão!

Quebrei a cara e perdi o balançado

Quando os jornais me deram conta da notícia

Que eu só perdi porque fui tapeado...

Pois nesse dia deu o bode...

Pra polícia! (O bom cabrito não berra be e e e).

O arbítrio e os maus tratos com que a polícia tem tradicionalmente lidado com as classes populares aparecem em Olha o Padilha de Ferreira Gomes, Bruno Gomes e Moreira da Silva:
Pra se topar uma encrenca

Basta andar distraído

Que ela um dia aparece

Não adianta fazer prece

Eu vim anteontem lá da gafieira

Com a minha nega Cecília

Quando gritaram: olha o Padilha!

Antes que eu me desviasse

Um tira forte aborrecido me abotoou

E disse: tu és o Nonô, heim

Mas eu me chamo Francisco

Trabalho como um mouro,eu sou estivador

Posso provar ao senhor

Nisso um moço de óculos ray-ban

Me deu um pescoção

Bati com a cara no chão

E foi dizendo: Eu só queria saber

Quem disse que és trabalhador

Tu és salafra e achacador

Essa macaca a teu lado é uma mina

Mais forte que o Banco do Brasil

Eu manjo ao longe jiu-jitsu

E jogou uma melancia pela minha calça adentro

Que engasgou no funil

Eu bambeei e ele sorriu

Apanhou uma tesoura

E o resultado desta operação 
E que a calça virou calção

Na chefatura um barbeiro sorridente

Estava a minha espera.

Ele ordenou: raspa o cabelo desta fera

Não está direito, seu Padilha

Me deixar com o coco raspado

Eu já apanhei um resfriado

Isso não é brincadeira

Pois o meu apelido era Chico Cabeleira

Não volto mais à gafieira.

Mas é Acertei no Milhar, samba composto por Wilson Batista ${ }^{12}$ e Geraldo Pereira, que se constitui no ideal da salvação pela sorte grande:

- Etelvina, minha filha!

- Que há, Jorginho?

Acertei no milhar

Ganhei 500 contos

Não vou mais trabalhar

E me dê toda roupa velha aos pobres

E a mobília podemos quebrar

Isto é pra já

Passe pra cá

Etelvina

${ }^{12}$ Vale também ressaltar que Wilson Batista compôs, em parceria com Haroldo Lobo, o célebre samba Emília, que caracteriza junto com Ai que saudades da Amélia de Ataulfo Alves e Mário Lago, o que Berlinck, em sua tipologia das imagens femininas presentes no samba, chamou apropriadamente de "mulher doméstica", ou como diz o próprio samba Emília: "uma mulher que saiba lavar e cozinhar" (ver Berlinck, op. cit.).
Vai ter outra lua-de-mel

Você vai ser madame

Vai morar num grande hotel

Eu vou comprar um nome não sei onde

De marquês, Dom Jorge Veiga, de Visconde

Um professor de francês, mon amour

Eu vou trocar seu nome

Pra madame Pompadour

Até que enfim agora eu sou feliz

Vou percorrer Europa toda até Paris

E os nossos filhos, heim?

- Oh, que inferno!

Eu vou pô-los num colégio interno

Me telefone pro Mané do armazém

Porque não quero ficar

Devendo nada a ninguém

Eu vou comprar um avião azul

Pra percorrer a América do Sul

Aí de repente, mas de repente

Etelvina me chamou

Está na hora do batente

Etelvina me acordou

Foi um sonho, minha gente. 
Segundo Vasconcellos, a antítese otário/malandro, que se estende à contraposição entre a entrada do indivíduo na produção e a vadiagem, atinge seu ápice em Acertei no Milhar:

O pano de fundo aqui ainda é, como não poderia deixar de ser, a prontidão: a possibilidade todavia de sair dela, ou de ludibriá-la, ocorre agora no plano onírico, no plano do imaginário. Logo no início da música irrompe o vocativo, bem-vindo e saltitante, comunicando a súbita guinada na vida do aspirante a vadio: 'Etelvina! Acertei no milhar/ ganhei quinhentos contos/ não vou mais trabalhar'. E a felicidade finalmente bate à porta com tudo: viagens pela Europa e América do Sul, os filhos no colégio interno, a conta do armazém liquidada, sombra e água fresca: no entanto, a trip na periferia, mais do que em qualquer outro lugar, tem um efeito passageiro:

'Mas de repente/ Etelvina me chamou/ está na hora do batente/ foi um sonho minha gente!' No samba de Geraldo Pereira, a saída via malandragem, não obstante a tirada irônica, entra em pânico a nível concreto: mas ainda não seria esse o momento do seu enterro definitivo na música popular. Nele se repete, apesar de tudo, o horror ao batente, a atitude malandra por excelência ${ }^{13}$

Vale lembrar que foi um dos compositores de Acertei no Milhar que se viu envolvido na célebre polêmica com Noel Rosa que, como se sabe, começou quando este resolveu ironizar Wilson Batista por ter composto, em 1933, o samba Lenço no Pescoço que dizia:

\section{Meu chapéu do lado}

Tamanco arrastando

Lenço no pescoço

Navalha no bolso

Eu passo gingando

Provoco e desafio

Eu tenho orgulho

Em ser tão vadio

\footnotetext{
${ }^{13}$ Vasconcellos, op. cit., p. 106-7.
}

Sei que eles falam

Deste meu proceder

Eu vejo quem trabalha

Andar no miserê

Eu sou vadio

Porque tive inclinação

Eu me lembro, era criança

Tirava samba-canção

Comigo não

Eu quero ver quem tem razão

\section{E eles tocam \\ E você canta \\ E eu não dou.}

Esse samba que é uma verdadeira exaltação à figura do malandro ("Eu tenho orgulho em ser vadio") representa a rejeição explicita do trabalho que se dá por motivos conscientes ("Eu vejo quem trabalha andar no miserê"). Além da prontidão e da valentia, outra imagem que está presente é a tão decantada índole preguiçosa do brasileiro ("Eu sou vadio porque tive inclinação") que também aparece no samba, analisado anteriormente, Caixa Econômica ("Por isso eu nasci cansado/ E pra falar com justiça/ Eu declaro aos empregados/ Ter em mim esta preguiça/ Herança de antepassados"). É como se houvesse um caráter nacional brasileiro que tivesse como um de seus arquétipos atávicos o personagem Macunaíma. $\mathrm{O}$ malandro constituir-se-ia, assim, no herói sem nenhum caráter, motivo de orgulho da "raça brasileira", fundando uma nova lógica ("Eu quero ver quem tem razão").

Noel era um boêmio por excelência, o que era característico de certos setores da classe média à qual pertencia. Entretanto, apesar de sua 
simpatia e contatos com a malandragem, sua origem pequenoburguesa talvez tenha sido um dos motivos que o levou a considerar a imagem do malandro, contida em Lenço no Pescoço, com a de um elemento de baixa categoria, violento e perigoso. Assim, Noel resolveu ironizar Wilson Batista, compondo o samba Rapaz Folgado no qual diz ao jovem compositor que coloque sapato e gravata, criticando sua visão "selvagem" da malandragem:

Deixa de arrastar o teu tamanco

Pois tamanco nunca foi sandália

Tira do pescoço o lenço branco

Compra sapato e gravata

Joga fora essa navalha que te atrapalha

Com o chapéu do lado deste rata

Da polícia eu quero que escapes

Fazendo um samba-canção

Já te dei papel e lápis

Arranje um amor e um violão

Malandro é palavra derrotista

Que só serve pra tirar

Todo valor do sambista

Proponho ao povo civilizado

Não te chamar de malandro

E sim de rapaz folgado.

O malandro passa a ser visto como uma figura negativa ("Malandro é palavra derrotista") e, em troca, é sugerido um termo mais ameno ("Proponho ao povo civilizado não te chamar de malandro e sim de rapaz folgado"). Não cabe aqui reconstituir todo desenvolvimento das músicas que compõem a polêmica entre Noel e Wilson Batista. ${ }^{14}$ Do

\footnotetext{
${ }^{14}$ As músicas que compõem a polêmica entre Noel Rosa e Wilson Batista foram gravadas no
} disco Polêmica da gravadora Odeon (MODB-3.033). ponto de vista deste trabalho, é mais importante analisar como os temas da malandragem, do trabalho, da mulher e do prazer comparecem nas músicas desta época.

Pode-se perceber, por algumas das composições aqui referidas, não só que o trabalho aparece como uma instituição da qual se deve fugir, mas também que a temática afirma uma impossibilidade de compatibilizar o mundo do trabalho com o do prazer que fica concentrado num determinado tipo de personagem feminino. $\mathrm{Na}$ verdade, a figura feminina é essencial e, ao mesmo tempo, ambivalente, representando, por um lado, uma fonte potencial de prazer na condição de amante, mas significando também, na mesma condição, a mulher piranha que, ao abandonar o malandro, o transforma em otário. Num pólo oposto, a mulher representa menos o prazer e mais a instituição da família enquanto aparelho ideológico de Estado, funcionando como agente do princípio da realidade, ou seja, simbolizando a exigência de trazer dinheiro para casa e a monotonia do cotidiano (como no samba homônimo de Chico Buarque $)^{15}$.

A imagem da mulher enquanto representante do pólo da ordem, lembrando a necessidade de o homem se inserir no processo produtivo, está presente em Capricho de Rapaz Solteiro, samba de 1933 de Noel, que afirma:

Nunca mais esta mulher

Me vê trabalhando

Quem vive sambando

Leva a vida

Para o lado que quer

De fome não se morre

Neste Rio de Janeiro

Ser malandro é um capricho

De rapaz solteiro.

\footnotetext{
${ }^{15}$ Ver Berlinck, op. cit.
} 
A letra deixa clara a aversão pelo trabalho, que é encarado como um fardo, e manifesta que o prazer (masculino) só seria possível fugindo do batente e optando pela malandragem. Esta, na verdade, é vista como um capricho que não é acessível a todos mas só a solteiros, já que a mulher fatalmente empurraria o homem para a monotonia do trabalho. Mas como a opção é feita a favor do pólo do prazer, a solução para o problema da sobrevivência é encarada em termos mágicos ("Quem vive sambando leva a vida para o lado que quer/ De fome não se morre neste Rio de Janeiro"). Em outras palavras, um capricho que não pode ser satisfeito por todos.

Em outros sambas de Noel evidencia-se com clareza uma concepção de que a mulher não deve trabalhar fora de casa. É interessante comparar duas de suas músicas em que isto se verifica claramente, embora em ambas o narrador esteja em situações econômicas diferentes.

A primeira é Você vai se quiser, samba composto por Noel para Lindaura, sua esposa que, cansada de ser sustentada pela sogra, decidiu trabalhar. A primeira estrofe da música mostra claramente um conflito:

$$
\begin{aligned}
& \text { Você vai se quiser } \\
& \text { Pois a mulher } \\
& \text { Não se deve obrigar } \\
& \text { A trabalhar } \\
& \text { Mas não vá dizer depois } \\
& \text { Que você não tem vestido } \\
& \text { E o jantar não dá pra dois. }
\end{aligned}
$$

Embora o narrador acredite que não se deva obrigar a mulher a trabalhar, seu trabalho é percebido como necessário para complementar o orçamento doméstico ("Mas não vá dizer depois/ Que você não tem vestido/ E o jantar não dá pra dois").

A continuação da letra da música (que é de 1936, quando a legislação getulista já tinha estendido o direito de voto e outros à mulher brasileira) afirma uma posição nitidamente machista:
Todo cargo masculino

Seja grande ou pequenino

Hoje em dia é pra mulher...

E por causa dos palhaços

Ela esquece que tem braços:

Nem cozinhar ela quer!

Os direitos são iguais...

Mas até nos tribunais

A mulher faz o que quer...

Cada qual que cave o seu

Pois o homem já nasceu

Dando a costela à mulher!

A mensagem é bastante clara: à esposa é permitido trabalhar fora, caso seja necessário para complementar o orçamento doméstico, mas isto não deve liberá-la de funções tradicionais de dona-de-casa ("Nem cozinhar ela quer!"), nem lhe permite ocupar cargos de liderança tradicionalmente mantidos por homens, já que seria um ser inferior ("Pois o homem já nasceu/Dando a costela à mulher!"). Entra em cena a dupla jornada de trabalho feminino.

Mas o samba de Noel no qual as oposições trabalho/ prazer, mulher trabalhadora/ mulher doméstica comparecem com maior clareza é em Três Apitos:

\section{Quando o apito}

Da fábrica de tecidos

Vem ferir os meus ouvidos

Eu me lembro de você

Mas você anda

Sem dúvida bem zangada 
Ou está interessada

Em fingir que não me vê

Você que atende ao apito

De uma chaminé de barro

Por que não atende ao grito

Tão aflito

Da buzina do meu carro?

Você no inverno

Sem meias vai pro trabalho

Não faz fé com agasalho

Nem no frio você crê

Mas você é mesmo

Artigo que não se imita

Quando a fábrica apita

Faz reclame de você

Nos meus olhos você lê

Como sofro cruelmente

Com ciúmes do gerente

Impertinente

Que dá ordens a você

Sou do sereno

Poeta muito soturno

Vou virar guarda-noturno
E você sabe por quê

Mas você não sabe

Que enquanto você faz pano

Faço junto do piano

Esses versos pra você.

O enredo da música envolve duas personagens: uma operária da indústria têxtil (que é um dos ramos através dos quais se iniciou a industrialização no Brasil e que se desenvolveu absorvendo muita mão-de-obra feminina) e um homem, presumivelmente de posses (o que se pode deduzir do fato de ter automóvel que era, na década de trinta, uma mercadoria bem mais escassa que atualmente), e que faz versos e toca piano. O desejo do narrador é salvar a operária do "gerente impertinente que dá ordens a você" e presumivelmente tê-la para atender seus desejos ("Por que não atende ao grito/ Tão aflito/ Da buzina do meu carro?”).

Embora a música trate da condição operária, ela fetichiza todas as relações a ponto de transformar a mulher em mercadoria ("Mas você é mesmo artigo que não se imita"). Nada é dito sobre as relações dentro da fábrica e as condições de trabalho a que eram submetidas as operárias das indústrias têxteis de então. O conflito, do modo como é apresentado pela letra da música, não passa de uma medição de força entre dois homens poderosos, cada qual com sua arma (a buzina do carro e o apito da fábrica). É lógico que estes dois homens representam também dois tipos diferentes de agentes sociais no que diz respeito ao processo produtivo: um, como expressa seu cargo, gere o capital; o outro, presumivelmente, vive de rendas, e num gesto de Príncipe Encantado quer retirar a mulher do processo produtivo que seria, em última análise, o meio onde ela poderia adquirir os elementos para refletir sobre sua condição de operária e de mulher, muito mais do que se transformasse em amante ou esposa nãoenvolvida em trabalho extradoméstico.

É lógico que, apesar de sua perspicácia, nem todas as composições de Noel têm um cunho social: "Essa crítica social, se existiu nele, era moderada e quase limitada a uma paródia de si mesmo - a mistificação do sambista, do malandro e do boêmio, em oposição aos 
seus grandes inimigos: o trabalho, os credores e a polícia. Mais importante talvez era a absoluta falta de cerimônia com que Noel tratava o seu próprio meio de expressão $(\ldots)^{16}$.

Mas apesar de ser um compositor originário da classe média e, portanto, refletir suas contradições, Noel era sensível às transformações que estavam se operando no interior da sociedade brasileira e que prefiguravam a formação de uma sociedade urbanoindustrial em que o trabalho assalariado, e principalmente fabril, se tornaria uma realidade cada vez mais flagrante. A partir daquela época fica cada vez mais difícil sobreviver da malandragem, que é mais um ideal que uma realidade facilmente acessível a quem quisesse. É o que se deduz de uma entrevista que o compositor concedeu ao jornal $O$ Globo, em 31 de dezembro de 1932:

Antes a palavra samba tinha um único sinônimo: mulher. Agora já não é assim. Há também o dinheiro, a crise. O nosso pensamento se desvia também para esses gravíssimos temas. O problema da vida, seriamente agravado pelas nossas manias de complicar as coisas mais simples, teria de imprimir novos rumos para o samba. Agora o malandro se preocupa no seu samba, quase tanto com o dinheiro, como com a mulher. A mulher e o dinheiro, afinal, são as únicas coisas sérias desse mundo.

E numa clara percepção de que estava ocorrendo, por parte de outras classes sociais, uma apropriação do samba que surgira como manifestação das classes subalternas, as quais também estavam sendo atingidas pelas transformações em curso no resto da sociedade, o compositor conclui:

O samba está na cidade. Já esteve é verdade no morro, isso no tempo em que não havia aqui embaixo samba. Quando a bossa nasceu, a cidade derrotou o morro. O samba lá de cima perdeu o espírito, o seu sabor inédito. Em primeiro lugar, o malandro sofreu uma transformação espantosa. Antes era diferente; agora está mais ou menos banalizado. A civilização começa a subir o morro, levando as suas coisas boas e suas coisas péssimas ${ }^{17}$.

\footnotetext{
${ }^{16}$ Castro, Ruy. Brasil rima com anil. Isto É (77): 36, 14 jun. 1978

${ }^{17}$ Apud Música popular brasileira. São Paulo, Abril (9): 9, 1976.
}

É importante recordar que Noel viveu numa época de mudanças que ocorreram tanto a nível da economia e da política, quanto a nível da música popular. Trata-se do período que coincide com a formação da indústria cultural no Brasil. A indústria fonográfica iniciou, em 1902, com a gravação do lundu de Xisto Bahia, Isto é Bom, e afirma-se que em 1917 Donga se tornou o primeiro compositor a gravar uma música com a designação de samba, o famoso Pelo Telefone. Em 1923, foi fundada a primeira emissora de rádio, a Rádio Sociedade, e no ano seguinte, a Rádio Clube do Brasil.

A música popular, que até então tinha um acesso bastante restrito à massa da população, encontrará no rádio um veículo que lhe dará um público que vai tender a se expandir rapidamente, abarcando parcelas cada vez maiores de ouvintes. Analisando as transformações que se operam nessa época na cultura popular, Sant'Anna assinala que na década de trinta "a música popular, ou melhor, o samba, já não é uma atividade característica de ex-escravos ou de negros e mestiços em ascensão social. Começam a surgir os primeiros compositores brancos de importância (...)"18. O que ocorreu com o samba é um fenômeno comum em relação à cultura popular brasileira: uma manifestação cultural que se origina nas classes dominadas e que é, no início, reprimida e frequentemente tratada como "caso de polícia"19, é apropriada por outras classes sociais, e passa a ser aceita e veiculada como autêntico símbolo da cultura nacional, tema que será analisado mais detidamente no próximo capítulo.

Embora as primeiras emissoras de rádio funcionassem de modo muito precário e dependessem de contribuições de ouvintes para se manter, a partir da década de trinta, o rádio cresce através da publicidade de mercadorias e serviços e vai se tornar o meio de comunicação hegemônico até ser suplantado pela televisão que surge na década de cinquenta.

Não é pois casual que Getúlio Vargas tenha percebido a importância deste novo meio de comunicação de massa, tendo sido o primeiro político latino-americano a se valer dele como instrumento de

${ }^{18}$ Sant' Anna, Affonso Romano de. Música popular e moderna poesia brasileira. Petrópolis, Vozes, 1977, p. 186

${ }^{19}$ Sodré, Muniz, op. cit. 
propaganda, o que fica claro numa mensagem enviada ao Congresso no dia $1^{\circ}$ de maio de 1937 na qual afirma que "à radiofonia está reservado o papel de interessar todos por tudo quanto se passa no Brasil" e que "no interior, torna-se necessário realizar uma obra de educação cívico-política, reforçando o conhecimento do regime democrático e seu funcionamento, dando a conhecer, em toda a extensão do país, qual a orientação dos seus dirigentes e o alcance das medidas administrativas em curso" 20.

O "regime democrático" a que se referia Getúlio cairia por terra seis meses mais tarde com a instauração do Estado Novo, cujo texto de proclamação significativamente foi transmitido na íntegra através do rádio pela voz do próprio presidente. A implantação da ditadura do Estado Novo obviamente teria importantes repercussões sobre a cultura $^{21}$, principalmente com a criação do Departamento de Imprensa e Propaganda (DIP) em 27 de outubro de 1939. Era natural que um dos alvos do DIP fosse o rádio, para o qual foi criada uma divisão que, de acordo com uma publicação oficial, tinha "a seu cargo, não apenas superintender todos os serviços de radiodifusão no país, como também orientar o rádio brasileiro em suas atividades culturais, sociais e políticas. A cooperação, a coordenação das atividades culturais do rádio, a unidade de espírito e de esforços que hoje reina nessa importante esfera da vida nacional, é obtida graças à orientação impressa nesse setor do DIP numa atmosfera de perfeita compreensão e espontânea colaboração de todas as emissoras" 22 .

Neste sentido é criada a Hora do Brasil, programa de uma hora de duração obrigatoriamente transmitido por todas as emissoras justamente entre as 19 e 20 horas quando a maioria da população está em casa. O programa tinha uma parte falada e outra musical que difundia música sinfônica, música popular e bandas de música.

${ }^{20}$ Apud Cabral, Sérgio. Getúlio e a música popular brasileira. Ensaios de Opinião (2-1): 39, 1975.

${ }^{21}$ Ver Mota, Carlos Guilherme. Cultura e política no Estado Novo (1937-1945). Encontros com a Civilização Brasileira (7), 1979.

${ }^{22}$ Cultura Política, ano II, 20, 1942. Apud Herd, Erika Francziska. A importância política do rádio. Revista de Cultura Vozes, 73 (8): 33-4, 1979.
$\mathrm{O}$ raio de ação do DIP torna-se abrangente ao ponto de adquirir "absoluto controle da música popular brasileira e de qualquer manifestação a ela relacionada". Assim, "nos concursos de músicas carnavalescas, nos desfiles de carnaval, nas estações de rádio, nas gravadoras de discos, em tudo estava a mão do DIP",23.

Noel Rosa faleceu em 1937, ano da criação do Estado Novo. Para Sant'Anna "assim como foi lícito aproximar Noel Rosa do Modernismo, é possível um paralelo entre Ari Barroso e o ufanismo ululante e oficial incrementado na década de $30 \mathrm{com}$ a ditadura de Getúlio Vargas"24. Neste sentido é significativo que Aquarela do Brasil tenha obtido o primeiro lugar num concurso de música popular promovido pelo DIP.

Mas além de promover na música popular uma imagem ufanista do Brasil, o governo estava empenhado em integrar o crescente proletariado à disciplina do trabalho fabril. A prévia criação do Ministério do Trabalho e da legislação trabalhista, bem como outras medidas, já indicavam esta orientação. Um dos alvos do DIP foi, portanto, reverter a tendência dos sambistas de exaltar a malandragem, incentivando os compositores a enaltecer o trabalho e a abandonar as referências elogiosas à malandragem.

Isto se refletiu, por exemplo, na obra de Wilson Batista. O mesmo compositor do célebre Lenço no Pescoço, autêntica exaltação do malandro que tanto irritou Noel, acaba compondo com Ataulfo Alves o samba $O$ Bonde de São Januário lançado no carnaval de 1941:

Quem trabalha é que tem razão

Eu digo e não tenho medo de errar

O bonde São Januário

Leva mais um operário:

Sou eu que vou trabalhar

Antigamente eu não tinha juízo

\footnotetext{
${ }^{23}$ Cabral, op. cit., p. 40.

${ }^{24}$ Sant'An.na, op. cit., p. 198
} 
Mas resolvi garantir meu futuro

Vejam vocês:

Sou feliz, vivo muito bem

A boemia não dá camisa a ninguém

É, digo bem.

De acordo com algumas versões, a letra original afirmava que "o bonde São Januário leva mais um otário" e que por pressão do DIP a palavra "otário" foi substituída por "operário", tendo o samba assim se transformado numa apologia do trabalho ${ }^{25}$.

Ataulfo Alves, o parceiro de Wilson Batista em O Bonde de São Januário, também compôs O Negócio é Casar no qual afirma:

Não sou mais aquele

Que entrava em casa alta madrugada

Faça o que eu fiz

Porque a vida é do trabalhador

O Estado Novo veio para nos orientar

No Brasil não falta nada

Mas precisa trabalhar.

É claro que o tema da "regeneração" do malandro (geralmente por influência de uma mulher ou da família) é recorrente na música popular brasileira ${ }^{26}$, mas, vindo de um vadio convicto como Wilson Batista, o caso parece mais de cooptação do artista pelo DIP ${ }^{27}$.

${ }^{25}$ Apud Música popular brasileira. São Paulo, Abril (34): $2^{\mathrm{a}}$ capa, 1978.

${ }^{26}$ Ver, como exemplos de falsas regenerações, os sambas A Malandragem de Bide e Francisco Alves, lançado no carnaval de 1928 e A Volta do Boêmio de 1956 de Adelino Moreira.

${ }^{27}$ Uma publicação de 1941, altamente apologética do Estado Novo, afirma que "O qualificativo 'malandro' corrompeu-se com o tempo. Agora designa o indivíduo esperto, que não se deixa iludir, e, também, não se lamenta, salvo quando a cabrocha abandona o 'barraco'... Não é mais, pois, o malandro, homem da desordem, que agride, que mata. A navalha e o revólver foram substituídos pelo pandeiro, pelo violão, pelo cavaquinho. É tangendo esses instrumentos que ele 'desacata'. Aquele tipo clássico, de calças largas e
A mesma linha de exaltação do trabalho é encontrada no samba $E u$ trabalhei lançado no carnaval de 1941 por Roberto Roberti e Jorge Faraj:

Eu hoje tenho tudo que um homem quer

Tenho dinheiro, automóvel e mulher

Mas para chegar até o ponto em que cheguei

Eu trabalhei, trabalhei, trabalhei

E hoje sou feliz

E posso aconselhar

Quem faz o que eu já fiz

Só pode melhorar

E quem diz que o trabalho

Não dá camisa a ninguém

Não tem razão. Não tem. Não tem.

Mostrando como os vários sambas e marchas do Estado Novo que enalteciam o trabalho eram resultado de uma imposição, Sérgio Cabral $^{28}$ assinala que foi suficiente a queda de Vargas em 1945 para que, no carnaval de 1946, se voltasse ao padrão anterior exemplificado no samba Trabalhar eu não de Almeidinha:

Eu trabalho como um louco

inteiriças, de salto carrapeta, chapéu de banda, desapareceu. Civilizou-se. No lugar do lenço, a gravata. Não senta mais à beira do barranco para compor sambas. Vem para a Avenida. Vem fazê-los à mesa do Nice. Usa roupas de bom alfaiate. A transformação foi completa. E explicável. Facilmente explicável. Valorizou-se a música popular. Habilidades foram aproveitadas $\mathrm{O}$ povo canta. Os salões repetem. Dão sua arte, seu talento à poesia, à música popular, nomes de realce. O povo, que é sempre justo, aprecia, sente no interessante 'argot' das trovas musicadas, nos queixumes e nas alegrias dos cancioneiros 'do morro' toda a policromia da própria vida que passa na simplicidade da verdade dita, que dia a dia nos depara. O homem das favelas, agora, vinga-se, zomba batendo chapéu de palha e tangendo o 'pinho', orando à lua, cuja luz entra pelos buracos do zinco, iluminando todo o 'barraco'... A bondade dos que governam influi, reflete-se direta e profundamente na consciência popular" (Cruz, H. Dias da. Os morros cariocas no novo regime. Rio de Janeiro, Gráfica Olímpica, 1941, p. 15-6).

${ }^{28}$ Cabral, op. cit., p. 40. 
Até fiz calo na mão

O meu patrão ficou rico

E eu pobre sem tostão

Foi por isso agora

Eu mudei de opinião

Trabalhar, eu não, eu não

Trabalhar, eu não, eu não.

Aqui, novamente, a rejeição do trabalho se dá por motivos conscientes ("Eu trabalho como um louco/ Até fiz calo na mão/ O meu patrão ficou rico/ E eu pobre sem tostão"). A música lembra Lenço no Pescoço de Wilson Batista ("Eu vejo quem trabalha andar no miserê"), já que a labuta é rejeitada por não constituir uma forma de qualificação numa sociedade que condena o trabalhador à miséria, não lhe assegurando condições de viver decentemente com os frutos de seu trabalho.

Neste sentido, é interessante analisar a letra do samba Izaura, de 1949, de Herivelto Martins e Roberto Roberti, ambos antigos "fregueses" dos cachês do DIP. Os tempos (Governo Dutra), obviamente, eram outros e não havia por que fazer o elogio ufanista do trabalho da época do Estado Novo. Mas, em vez de refletir a oposição básica entre capital e trabalho, o que se verifica é um deslocamento deste conflito e sua transformação num outro tipo de problemática, escamoteando-se, assim, a natureza da sociedade de classes:

\section{Ai, ai, ai, Izaura}

Hoje eu não posso ficar

Se eu cair nos seus braços

Não há despertador

Que me faça acordar

Eu vou trabalhar
O trabalho é um dever

Todos devem respeitar

Oh! Izaura, me desculpe

No domingo eu vou voltar

Seu carinho é muito bom

Ninguém pode contestar

Se você quiser eu fico

Mas vai me prejudicar

Eu vou trabalhar.

O que ocorre na letra desse samba é a transformação do conflito entre trabalho e capital em conflito entre trabalho e prazer. Esta operação não só ignora o conflito central da sociedade de classes, mas também concebe como impossibilidade conciliar a esfera do trabalho com a do prazer. Isto possivelmente tem a ver com a ideia de uma cultura tropical onde não prevaleceriam os princípios que operam em outras terras, concepção esta detectada por Oswald de Andrade quando afirmou que, aqui nos trópicos, o contrário do burguês é o boêmio e não o proletário.

Examinando-se a letra do samba, nota-se que ele é dominado por uma decisão firmemente produtivista ("Eu vou trabalhar") que coloca neste momento o narrador no pólo da seriedade. Mas a composição é toda ela perpassada por uma visão do trabalho como algo alienante e externo ao homem ("O trabalho é um dever/ Todos devem respeitar") e não como uma relação dos homens entre si e com a natureza.

Ao contrário, a letra da música relaciona-se com o mito bíblico da expulsão do paraíso que condena o homem ao trabalho ao obrigá-lo a ganhar o pão com o suor de seu rosto. Há uma oposição que se consubstancia na dicotomia natureza versus prazer, natureza sendo aqui simbolizada pelo trabalho que seria apenas a luta para dominar o meio ambiente e não também uma relação entre homens. Neste sentido é significativo que o prazer fique deslocado para o domingo, justamente o dia em que o homem, por não trabalhar, não atua sobre a natureza. Apenas então haveria lugar para o prazer. Em qualquer 
outro dia, "ficar" (e portanto optar por usufruir do prazer) significa ser "prejudicado", já que trabalho e prazer são vislumbrados como mutuamente exclusivos.

Mas o Brasil depois da Segunda Guerra já apresentava outra realidade. A crise internacional do capitalismo a partir de 1929 e a conflagração mundial significaram para o país um novo processo de substituição de importações. Assim, entre 1929 e 1937, a produção industrial cresceu em aproximadamente $50 \%$ e no final da guerra a manufatura já era responsável por cerca de $20 \%$ de nosso produto doméstico bruto.

Como consequência, o número de operários e assalariados aumentou acentuadamente. Junto, obviamente, veio a disciplina exigida pelo trabalho fabril. O legado da legislação trabalhista criada por Vargas foi mantido pela Constituição de 1946, o que significou a inviabilidade de uma verdadeira organização do operariado, já que os sindicatos continuavam atrelados ao Ministério do Trabalho e os novos partidos eram no máximo para trabalhadores, mas nunca dos trabalhadores. Assim, "o novo se mantinha preso ao passado. Nosso capitalismo continuava com um pé na Lapa, em escusos galpões de fundo de praia, enlevado pelas mamatas, e nostálgico da capatazia da fazenda" 29.

É natural que estas transformações se refletissem na música popular brasileira. Num processo de apropriação do que era inicialmente perseguido e proibido, a malandragem, originária das classes baixas e centradas na Lapa, acabou sendo incorporada por alguns boêmios da zona sul do Rio de Janeiro. É o que fica claro numa composição de 1953 de John Alf, um dos expoentes da bossa-nova, denominada Rapaz de Bem, título que lembra o samba Rapaz Folgado com que Noel espinafrou Lenço no Pescoço, de Wilson Batista, iniciando a célebre polêmica:

Você bem sabe, eu sou rapaz de bem

E minha onda é do vai e vem

\footnotetext{
${ }^{29}$ Vianna, Luis Werneck. O americanismo: da pirataria à modernização (e o que se pode seguir), in: Buarque de Hollanda, Chico. Ópera do Malandro. São Paulo, Cultura, 1979, p.12.
}

Pois com as pessoas que eu bem tratar

Eu qualquer dia posso me arrumar

Vê se mora

No meu preparo intelectual

E o trabalho a pior moral

Não sendo a minha apresentação

O meu dinheiro só de arrumação

Eu tenho casa, tenho comida

Não passo fome, graças a Deus

E no esporte eu sou de morte

Tendo isso tudo eu não preciso de mais nada

É claro

Se a luz do sol vem me trazer calor

A luz da lua vem trazer amor

Tudo de graça a natureza dá

Pra que que eu quero trabalhar?

O contexto, obviamente, não era mais a Lapa. Mas, além do estilo de vida próprio da zona sul (a zona "bem") do Rio de Janeiro, o que a letra reafirma é a rejeição do trabalho ("É o trabalho a pior moral"), mas desta vez menos pela dificuldade de integrar ao mundo da atividade assalariada e sua disciplina e mais por falta de necessidade ("Eu tenho casa, tenho comida/ Não passo fome, graças a Deus"). Em vez de ser bom de navalha, o "Rapaz de Bem" é mais sofisticado e esgrima as armas do esporte ("E no esporte eu sou de morte"). E, se "Tudo de graça a natureza dá/ Pra que que eu quero trabalhar?" Os últimos versos lembram, aliás, muito os versos do samba Capricho de Rapaz Solteiro de Noel, no qual afirma que "De fome não se morre/ Neste Rio de Janeiro".

Situação semelhante se percebe na composição Mocinho Bonito de Billy Blanco, lançado em 1956:

Mocinho bonito 
Perfeito improviso

Do falso grã-fino

No corpo é atleta

No crânio é menino

Que além do $\mathrm{ABC}$

Nada mais aprendeu

Queimado do sol

Cabelo assanhado

Com muito cuidado

Na pinta de conde

Se esconde um coitado

Um pobre farsante

Que a sorte esqueceu

Contando vantagem

Que vive de renda

E mora em palácio

Procura esquecer

Um barraco do Estácio

Lugar de origem

Que há pouco deixou

Mocinho bonito

Que é falso malandro

De Copacabana

$\mathrm{O}$ mais que consegue

É o “vintão" por semana

Que a mana do peito

Jamais lhe negou.
Na letra são satirizados os rapazes "bacanas", frequentadores das praias cariocas e metidos a galãs americanos. Em última análise o mocinho bonito é acusado de ser um "falso malandro", "um pobre farsante" que conta vantagem e "procura esquecer/ um barraco do Estácio/ lugar de origem/ que há pouco deixou".

Mas, se o que se verifica no intervalo democrático-liberal de 1946-64 é a aproximação do tema da malandragem por alguns compositores de classe média, o que se constata depois de 1964 é a falência da malandragem. Tome-se, por exemplo, a composição Conversa de Malandro, lançada em 1965, por Paulinho da Viola:

Não é conversa de malandro

Eu sempre fui malandro

Mas agora não gostei

De ver o seu sapateado

E quero conquistar seu coração

\section{Está crescente}

Esta amizade no meu peito

Estou contente

E já mandei construir

Para nós o caixote

E já encontrei batente

E lá no morro quando o sol chegar

E eu descer sorrindo para trabalhar

E alguém perguntar espantado

$\mathrm{O}$ que foi que aconteceu

Eu vou dizer

Que abandonei de fato a vida de orgia

E que vivendo assim sou mais feliz 
E na verdade o malandro sou eu.

Existem praticamente duas leituras possíveis deste samba. A primeira consistiria em considerá-lo apenas mais uma promessa de regeneração de um malandro apaixonado, promessa que obviamente não será cumprida (daí o título "Conversa de Malandro"). A segunda leitura consistiria em encará-lo como alguém que efetivamente assume o trabalho, pela impossibilidade de continuar a rejeitá-lo, justificando esta atitude pela paixão ("vivendo assim sou mais feliz/ E na verdade o malandro sou eu").

Neste sentido, Maar argumenta que, se na década de trinta, em que o país começou a esboçar os primeiros passos para a industrialização, a oposição ingênua ao trabalho era totalmente compreensível, atualmente, com o desenvolvimento industrial, a realidade sócioeconômica deixou pouco espaço de movimentação para o malandro.

Hoje quase todo mundo é obrigado a trabalhar para viver. O mecanismo da 'prestação de favores' que na realidade mantinha vivo o boêmio antigamente, praticamente desapareceu. $\mathrm{O}$ próprio imperativo: 'Vai trabalhar!', apesar de não perder seu caráter autoritário, de ordem, já não aparece mais como tal, pois que se tornou uma imposição geral. Como se universalizou, ninguém mais dá conta do seu lado agressivo. A atividade produtiva está na ordem do dia. (...) Se antigamente a malandragem consistia em sobreviver sem trabalhar, hoje seria sobreviver trabalhando. Agora quem não trabalha passa por vagabundo ${ }^{30}$.

Este tipo de problemática também comparece no samba Nega Dina lançado por Zé Keti em 1964 e incluído no show Opinião:

A Dina subiu o morro do Pinto

Pra me procurar

Não me encontrando, foi ao morro da Favela

Com a filha da Estela

Pra me perturbar

Mas eu estava lá no morro de São Carlos

${ }^{30}$ Maar, Wolfgang Leo. De malandro a vagabundo. Opinião (219): 22, 14 jan. 1977.
Quando ela chegou

Fazendo um escândalo, fazendo quizumba

Dizendo que levou

Meu nome pra macumba

Só porque faz uma semana

Que não deixo uma grana

Pra nossa despesa

Ela pensa que minha vida é uma beleza

Eu dou duro no baralho

Pra poder comer

A minha vida não é mole, não

Entro em cana toda hora sem apelação

Eu já ando assustado, sem paradeiro

Sou um marginal brasileiro.

Embora retome o estilo dos sambas da década de 30 e 40, a temática desta composição já deixa entrever outra situação. Parece que o compositor, prefigurando a crise da malandragem, que se delineia cada vez mais no horizonte brasileiro, principalmente depois de 1964, assume não mais o orgulho de ser malandro, mas a dificuldade em sobreviver ("A minha vida não é mole, não"), o medo e a falta de parâmetros ("Eu já ando assustado, sem paradeiro") e acima de tudo a sua situação ("Sou um marginal brasileiro"). E assim, de certo modo, executa o canto do cisne do malandro tradicional, embora o faça no estilo dos antigos malandros.

Mas o atestado de óbito do autêntico malandro foi passado por Chico Buarque na Homenagem ao Malandro:

\section{Eu fui fazer}

Um samba em homenagem

À nata da malandragem

Que conheço de outros carnavais 
Eu fui à Lapa

E perdi a viagem

Que aquela tal malandragem

Não existe mais

Agora já não é normal

O que dá de malandro

Regular, profissional

Malandro com aparato

De malandro oficial

Malandro candidato

A malandro federal

Malandro com retrato

Na coluna social

Malandro com contrato

Com gravata e capital

Que nunca se dá mal

Mas o malandro pra valer

— não espalha

Aposentou a navalha

Tem mulher e filho

E trabalha e tal

Dizem as más línguas

Que ele até trabalha

Mora lá longe e chacoalha

Num trem da Central.

Apesar do título ("Homenagem ao Malandro"), canta-se a falência do "malandro pra valer" que teve que se inserir nas malhas do processo produtivo, isto é, aposentou a navalha, tem mulher e filho e, pasmem, até trabalha tendo que se sujeitar aos trens da Central.

Estaria, entretanto, a malandragem realmente fadada ao desaparecimento por causa da erosão da base social que lhe deu origem? Conforme Vasconcellos, constituindo-se numa expressão de "falsa consciência", a metáfora da malandragem é uma resposta equivocada, mas subjetivamente justificada numa fase da sociedade brasileira. Para ele, "o malandro, tal como o boêmio, não faz história. Talvez ele possa se orientar pelos sintomas da evolução histórica, nunca porém pelo seu movimento real. No Brasil, como em todo lugar, os sujeitos da história são a burguesia e o proletariado" "31. Contudo, de acordo com o mesmo autor, de nada adiantaria expor a fantasmagoria da malandragem ou sua "falsidade", pois o que importa é apontar a necessidade social de seu aparecimento.

Mas, apesar do reduzido espaço social que sobra à vadiagem, a malandragem permanece enquanto um símbolo de identidade nacional, que pode em certas épocas significar até a capacidade de sobreviver trabalhando. O tema da apropriação, reelaboração e posterior transformação em símbolo nacional de manifestações culturais inicialmente restritas às classes dominantes será objeto de análise no próximo capítulo.

\footnotetext{
${ }^{31}$ Vasconcellos, op. cit., p. 108.
} 


\section{Capítulo IV}

\section{AS METAMORFOSES DA CULTURA BRASILEIRA*}

Este capítulo analisa um aspecto fundamental para a compreensão da sociedade brasileira: a dinâmica da produção e do consumo da cultura no Brasil. Ele se detém, especialmente, no exame do fenômeno da apropriação de manifestações culturais específicas a certos grupos sociais por parte do resto da sociedade e a sua transformação em símbolos nacionais.

Para aprofundar a análise da dinâmica da produção e do consumo da cultura no Brasil seria necessário examinar manifestações culturais que ocorrem no país, verificando, em primeiro lugar, em que grupos se originam e o que representam para eles. A seguir dever-se-ia analisar como são encaradas estas manifestações culturais pelo resto da sociedade e em que momento e por que motivos elas são apropriadas e reelaboradas por outros grupos. Finalmente seria preciso estudar os mecanismos através dos quais certas manifestações culturais que estavam inicialmente restritas a determinadas classes sociais tornam-se uma prática disseminada em toda sociedade e são ressemantizadas e transformadas em símbolos nacionais, assumindo assim um caráter de identidade brasileira.

Procurando desvendar as articulações entre o que tradicionalmente é chamado de cultura popular e o que tradicionalmente é chamado de cultura dominante, poder-se-ia lançar como hipótese a existência de pelo menos dois tipos de movimentos opostos.

* Texto apresentado na mesa-redonda "Cultura, Participação e Organização das Classes Populares no Meio Urbano" do simpósio "Antropologia e Movimentos Sociais" realizado em maio de 1981 na Universidade de Campinas e no simpósio "Nacionalismo e Universalismo: perspectivas do debate sobre o problema da identidade nacional no Brasil" realizado pelo Centro de Estudos Rurais e Urbanos em julho de 1981, em Salvador, na $33^{\text {a }}$ Reunião Anual da Sociedade Brasileira para o Progresso da Ciência.
O primeiro ocorre quando as classes dominantes se apropriam, reelaboram e posteriormente transformam em símbolos nacionais manifestações culturais originalmente restritas às camadas populares e que frequentemente eram reprimidas pelo Estado.

O segundo movimento percorre uma trajetória inversa e ocorre quando as classes populares se apropriam, reelaboram e posteriormente transformam em símbolos nacionais manifestações culturais originalmente restritas às classes dominantes e que frequentemente lhes conferiam uma marca de distinção.

O que há de comum a ambos os movimentos é a apropriação de expressões de outros grupos e sua recodificação e introdução num outro circuito no qual estes elementos são dotados de novo significado e, portanto, utilizados de forma a afetar seu significado original. $\mathrm{Na}$ verdade, este processo de ressemantização envolve um grau de complexidade bem maior do que pode parecer à primeira vista, já que, além da relação entre a cultura popular e a cultura hegemônica, envolve também a intervenção do Estado e a ação dos meios de comunicação de massa.

Analisando a primeira destas tendências (a maneira como a cultura hegemônica se orienta em relação à cultura popular), Menezes sugere a existência de três momentos no processo de dominação cultural. No primeiro, o da rejeição, a cultura popular é vista como "delito" ou "desordem" e contra ela são acionados os aparelhos repressivos como, por exemplo, a polícia. No segundo, o da domesticação, o aparelho científico das classes dominantes é utilizado para separar os componentes da cultura popular considerados perigosos daqueles considerados apenas figurativos ou exóticos. Esta é a fase da dominação simbólica que se caracteriza pelos registros, conceptualizações, tipologias, interpretações, teorias e modelos. No terceiro momento, o da recuperação, a ação simultânea dos aparelhos ideológicos e da indústria cultural transforma as expressões culturais das classes dominadas em itens codificados de museus e exposições, 
em mercadoria exótica para consumo turístico, em instrumentos ideológicos de inculcação pedagógica, etc ${ }^{1}$.

Seria interessante examinar algumas instâncias em que se verifica a apropriação e recodificação de traços culturais das classes subalternas por parte de outras classes sociais e sua transformação em símbolos nacionais. Entre os exemplos estariam a feijoada, o candomblé, a Umbanda, o samba, o tema da malandragem, etc.

Referindo-se ao primeiro destes exemplos, Fry assinala que enquanto nos Estados Unidos a feijoada é comida de negros (soul food), no Brasil ela é um prato nacional. "Está claro que a origem do prato é a mesma nos dois países, pois em ambos este item de cultura culinária foi elaborado pelos escravos utilizando as sobras do porco desprezadas por seus senhores. A diferença está no significado simbólico do prato. Na situação brasileira, a feijoada foi incorporada como símbolo da nacionalidade, enquanto nos Estados Unidos se tornou símbolo da negritude, no contexto do movimento de liberação negra" 2 .

Um processo da mesma natureza teria ocorrido em relação ao candomblé - religião em que as divindades africanas estariam escondidas atrás da fachada de santos católicos - e que foi no seu início reprimida pelas classes dominantes, que não vacilavam em utilizar para isto a polícia. Entretanto, apesar da repressão sofrida pelo candomblé, "a situação não era simplesmente a de uma oposição total, uma vez que os ogans dos centros de culto, posições honoríficas que conferiam certos direitos e privilégios, eram geralmente recrutados entre a própria elite repressora. Estes ogans ofereciam sua proteção e recebiam, em troca, votos e outros serviços. Já nessa época o candomblé, embora produzido pelos negros,

${ }^{1}$ Menezes, Eduardo Diatay B. de. Elitelore versus folclore, ou de como a cultura hegemônica tende a devorar a cultura subalterna. Trabalho apresentado no Seminário "Cultura Brasileira" realizado em junho de 1980, em Ouro Preto, pelo Grupo de Trabalho "Sociologia da Cultura Brasileira' da Associação Nacional de Pós-Graduação e Pesquisa em Ciências Sociais.

${ }^{2}$ Fry, Peter. Feijoada e soul food: notas sobre a manipulação de símbolos étnicos e nacionais. Ensaios de Opinião (2-2): 45, 1977. dependia para sua existência, pelo menos em certa medida, da elite branca" 3 .

Desde o final do século passado até nossos dias, o candomblé sofreu uma série de transformações que implicaram a gradativa aceitação e absorção dos terreiros mais tradicionais pela cultura de massa, pelo turismo, por parte da Igreja Católica e por vários intelectuais.

Um processo semelhante, porém talvez mais complexo, ocorreu em relação à Umbanda, religião que pode ser vista como produto das transformações sociais e econômicas que se verificam no país. Conforme Ortiz ${ }^{4}$, a Umbanda não é uma religião negra (em contraposição ao Candomblé, este sim tentando manter viva a memória coletiva africana). Ela se constituiria numa síntese do pensamento religioso brasileiro, sendo o resultado da fusão de dois movimentos: o embranquecimento da cultura negra e o empretecimento do espiritismo kardecista.

O substrato desta fusão pode ser resumido do seguinte modo: por um lado o negro só pode ascender socialmente nos marcos da cultura branca, precisando, portanto, ajustar sua herança africana aos cânones de uma sociedade na qual a ideologia branca é dominante. Por outro lado, como o branco e o mulato não podem negar a influência africana no Brasil, a ideologia umbandista reinterpreta a tradição afro-brasileira segundo as conveniências da cultura branca. É justamente na síntese das tradições afro-brasileiras e espíritas que reside a originalidade da Umbanda que representa uma tentativa de integração na sociedade brasileira.

É por isto que, para Ortiz, a verdadeira chave da compreensão da Umbanda é a própria sociedade brasileira e as mudanças sociais e econômicas que ela vem experimentando. Com efeito, a Umbanda surge no Brasil a partir da década de 1920 e especialmente 1930. O Primeiro Congresso Brasileiro Umbandista é realizado no Rio de Janeiro, em 1941, quando uma liderança de classe média e com orientação kardecista resolve estudar a religião e codificar seus ritos.

\footnotetext{
${ }^{3}$ Ibid., p. 45

${ }^{4}$ Ortiz, Renato. A morte branca do feiticeiro negro: Umbanda, integração de uma religião numa sociedade de classes. Petrópolis, Vozes, 1978.
} 
O papel da classe média é assim crucial na consolidação da nova religião.

Nesse sentido, Diana Brown sustenta que na década de cinquenta existiam duas interpretações bastante diferentes na Umbanda. A primeira tinha como substrato as classes subalternas concentradas em inúmeros terreiros afro-brasileiros, cujos frequentadores, embora não necessariamente descendentes de africanos, seguiam rituais de orientação afro-brasileira. A segunda interpretação tomava como base a classe média, que desenvolvia uma Umbanda marcadamente desafricanizada e frequentemente bem nacionalista. Entretanto, nenhuma dessas duas formas de Umbanda estava totalmente restrita a uma única classe social ${ }^{5}$.

É, pois, importante analisar o tipo de integração que a Umbanda opera. Ortiz mostra como ela reproduz as contradições da sociedade brasileira e se apropria de valores socialmente legítimos a fim de ser aceita numa sociedade que a princípio lhe foi hostil.

Cabe destacar, inicialmente, a tentativa de legitimação através do discurso pseudocientífico formulado pelos intelectuais umbandistas. Assim, por exemplo, justificam-se as bebidas pelas leis de atração e repulsão de Newton; os defumadores pela teoria fluídica, e as facas e espadas pela teoria eletrostática do poder das pontas.

Outro exemplo é o processo de "purificação" dos elementos africanos considerados "selvagens". Desta forma, embora o ritual umbandista absorva boa parte da estrutura e do funcionamento dos cultos afrobrasileiros, operam-se transformações importantes como a reintegração de Exu que é desdobrado em Exu-pagão (atrasado) e em Exu-batizado (beneficiado por alguns raios de luz). Do mesmo modo tendem a ser eliminadas as práticas relativas aos cultos africanos consideradas "bárbaras" como os rituais de sangue, o uso da pólvora, o sacrifício de animais e as comidas de santo. Enfatizam-se, em vez disto, valores de classe como a limpeza e a boa apresentação.

Fry assinala que, à semelhança do candomblé, o samba também foi apropriado e transformado em símbolo nacional. Na fase em que ele

${ }^{5}$ Brown, Diana. O papel histórico da classe média na Umbanda. Religião e Sociedade (1), 1977. era produzido e consumido no "morro", a polícia o reprimia com severidade, obrigando-o inclusive a se ocultar no candomblé, considerado então um pouco mais aceitável. Entretanto, com o passar do tempo, "a importância crescente do carnaval provocou a transformação da repressão em apoio manifesto. As escolas de samba desceram para as avenidas legitimamente e o samba passou a ser consumido por uma população que ultrapassara de muito as fronteiras do morro, do Rio de Janeiro ou mesmo do Brasil" 6 .

Também com o tema da malandragem na música popular brasileira ocorreu um processo de apropriação e ressemantização. Como se sabe, o fim da escravidão no Brasil não significou o surgimento de uma sociedade mais aberta, mas a continuidade do padrão de dominação oligárquica. Mesmo com a intensificação da industrialização, o trabalho assalariado não se torna uma forma de qualificação pois a ordem social continua sendo fortemente excludente. Assim, a malandragem, ao proclamar o "horror ao batente" e recusar o trabalho assalariado, se configura numa alternativa - transformada em estratégia de sobrevivência - numa sociedade que marginaliza o trabalhador, não lhe assegurando condições de viver decentemente do fruto de seu labor. Por isto é importante registrar que o tema da malandragem se desenvolve mais intensamente na música popular brasileira nas décadas de 1920, 30 e 40.

Nesta época, além do "horror ao batente" existe uma série de temas que são recorrentes em músicas de malandragem: a crônica "prontidão" (escassez de dinheiro), a "categoria", o jogo de cintura, a valentia, a lábia, o golpe no otário, a sátira ao arbítrio da polícia e suas ligações com o jogo, a salvação pela sorte grande, etc.

A imagem do malandro nestas músicas é muitas vezes a de um homem perigoso como na célebre composição de Wilson Batista: "Meu chapéu de lado/ Tamanco arrastando/ Lenço no pescoço/ Navalha no bolso/ Eu passo gingando/ Provoco e desafio/ Eu tenho orgulho/ Em ser tão vadio". É interessante que tenha sido justamente esta música de um autor então pouco conhecido que levou Noel Rosa

\footnotetext{
${ }^{6}$ Fry, op. cit., p. 47.
} 
a iniciar a célebre polêmica na qual ironiza Wilson Batista compondo Rapaz Folgado, no qual aconselha o jovem compositor a jogar fora a navalha e colocar sapato e gravata, propondo assim a depuração dos elementos mais "perigosos" da malandragem.

Mas apesar de ser um compositor de origem de classe média e, portanto, refletir suas contradições, Noel era sensível às transformações que estavam se operando no interior da sociedade brasileira e que prefiguravam a formação de uma sociedade urbanoindustrial em que o trabalho assalariado e, principalmente, o fabril, se tornariam uma realidade cada vez mais flagrante. A partir daquela época fica cada vez mais difícil sobreviver da malandragem, que é mais um ideal que uma realidade facilmente acessível a quem quisesse. Na verdade, Noel percebia que estava havendo, por parte de outras classes sociais, uma apropriação do samba que surgira como manifestação das classes subalternas, as quais também estavam sendo atingidas pelas transformações em curso no resto da sociedade. Numa entrevista publicada em O Globo de 31 de dezembro de 1932, Noel afirma: "O samba está na cidade. Já esteve, é verdade, no morro, isso no tempo em que não havia aqui embaixo samba. Quando a bossa nasceu, a cidade derrotou o morro. O samba lá de cima perdeu o espírito, o seu sabor inédito. Em primeiro lugar, o malandro sofreu uma transformação espantosa. Antes era diferente; agora está mais ou menos banalizado. A civilização começa a subir o morro, levando as suas coisas boas e suas coisas péssimas" 7 .

É importante recordar que Noel viveu no período que coincide com a formação da indústria cultural no Brasil. A música popular, que até então tinha um acesso bastante restrito à massa da população, encontrará no rádio um veículo que lhe dará um público que vai tender a se expandir rapidamente, abarcando parcelas cada vez maiores de ouvintes. Analisando as transformações que se operam nessa época na cultura popular, Sant'Anna assinala que na década de trinta "a música popular, ou melhor, o samba, já não é uma atividade característica de ex-escravos ou de negros e mestiços em ascensão

\footnotetext{
${ }^{7}$ Música popular brasileira. São Paulo, Abril, fascículo 9, 1976, p. 9.
}

social. Começam a surgir os primeiros compositores brancos de importância (...)" 8 .

Noel morreu em 1937, o ano da implantação do Estado Novo. Em 1939 foi criado o Departamento de Imprensa e Propaganda (DIP), que tinha uma divisão de rádio. O raio de ação do DIP tornou-se abrangente ao ponto de adquirir "absoluto controle da música popular brasileira e de qualquer manifestação a ela relacionada". Assim, "nos concursos de músicas carnavalescas, nos desfiles de carnaval, nas estações de rádio, nas gravadoras de discos, em tudo estava a mão do DIP" 9 .

Um dos alvos do DIP foi reverter a tendência dos sambistas a exaltar a malandragem. Assim, por um lado, ele começou a incentivar os compositores a enaltecer o trabalho e, por outro, a abandonar as referências elogiosas à malandragem. Isto se refletiu nas letras de vários compositores que antes exaltavam a malandragem e que de repente começam a enaltecer as virtudes do trabalho. É verdade que quando cai o Estado Novo alguns destes compositores voltam a fazer o elogio da malandragem.

Mas depois da Segunda Guerra a realidade brasileira já era outra, e o número de operários e demais assalariados cresceu em função do processo de substituição de importações que estava em curso. É natural que estas transformações se refletissem na música popular brasileira. Num processo de apropriação do que era inicialmente perseguido e proibido, a malandragem, originária das classes subalternas e centrada na Lapa, acabou sendo incorporada por alguns boêmios da zona sul do Rio de Janeiro.

Mas, se o que se verifica no intervalo democrático-liberal de 1946-64 é a apropriação do tema da malandragem por alguns cantores de classe média, com a intensificação do crescimento industrial no Brasil fica cada vez mais difícil sobreviver sem trabalhar. Isto fica bem retratado na Homenagem ao Malandro de Chico Buarque, onde,

${ }^{8}$ Sant'Anna, Affonso Romano de. Música popular e moderna poesia brasileira. Petrópolis, vozes, 1977 , p. 186

${ }^{9}$ Cabral, Sérgio. Getúlio Vargas e a música popular brasileira. Ensaios de Opinião (2-1): 40, 1975. 
apesar do título, canta-se a falência do "malandro para valer" que teve que se inserir nas malhas do processo produtivo, isto é, aposentou a navalha, tem mulher e filho e, pasmem, até trabalha tendo que se sujeitar aos trens da Central.

Mas, apesar do reduzido espaço social que sobra à vadiagem, a malandragem permanece enquanto um dos pólos de identidade nacional representada pela oposição malandro-“caxias”, captada por Da $\mathrm{Matta}^{10}$. Foi também o mesmo autor que elaborou uma interpretação a respeito do carnaval brasileiro como um rito de passagem através do qual a vida cotidiana é simbolicamente invertida ou neutralizada e as diferenças sociais são supostamente apaziguadas, ajudando assim a formar uma ideologia de encontro e comunhão.

Para fins da presente análise, é importante ressaltar os processos através dos quais o carnaval se transformou, constituindo-se atualmente numa "instituição paradigmática desta visão do Brasil como uma grande communitas, onde raças, credos, classes e ideologias comungam pacificamente ao som do samba e da miscigenação racial, aqui vista como um traço quase-hereditário do caráter nacional português" ${ }^{11}$.

Pode-se sugerir que o carnaval brasileiro, encarado numa perspectiva histórica, se enquadra na trajetória de uma manifestação cultural que, se originando nas classes dominantes, sofre gradativamente mudanças que significam o surgimento de formas populares de brincá-lo, as quais por sua vez serão incorporadas pelo resto da sociedade, transformando este festejo em símbolo nacional.

Como se sabe, o carnaval não foi trazido ao Brasil por escravos e posteriormente adotado por outros segmentos da população, mas veio com os primeiros colonizadores sob a forma de entrudo, tendo assim se conservado sem sofrer maiores modificações até aproximadamente meados do século passado.

A partir desta época, o desenvolvimento de um estilo de vida burguês europeu em algumas de nossas cidades, em decorrência do rápido

\footnotetext{
${ }^{10}$ Da Matta, Roberto. Carnavais, malandros e heróis. Rio de Janeiro, Zahar, 1979.

${ }_{11}$ Da Matta, Roberto. Carnavais, malandros e heróis. Rio de Janeiro, Zahar, 1979.
Id. O carnaval como um rito de passagem, in: - Ensaios de antropologia estrutural. Petrópolis, Vozes, 1973, p. 123.
}

enriquecimento trazido pela cafeicultura, deu origem ao carnaval "veneziano" que implicou o aparecimento de formas de divertimento restritas a diferentes camadas sociais. Assim, embora todas as camadas sociais promovessem seus bailes de máscaras em recintos fechados, a forma socialmente mais aceita de desfile era o corso. Através dele, as famílias mais ricas exibiam suas fantasias em veículos para serem assistidas e aplaudidas pelo resto da população. Por seu turno, os ranchos, cordões e blocos eram frequentemente proibidos e perseguidos pela polícia e acabaram por ser expulsos do centro das cidades, localizando-se nos bairros mais periféricos onde se tornaram modos típicos das classes subalternas brincarem o carnaval.

Segundo Pereira de Queiroz, “do ponto de vista sociológico, uma diferença flagrante separa o velho carnaval colonial do carnaval 'veneziano'. Nos tempos antigos do entrudo, os folguedos nas cidades tinham sido os mesmos para todas as camadas sociais. O aparecimento do carnaval 'veneziano' foi o sinal de uma diferenciação segundo hierarquias sócio-econômicas. A partir desse momento, notou-se claramente a influência de duas heranças culturais diversas: as camadas elevadas se divertiam à européia, com seu corso e seus préstitos suntuosos, ritmados pela música das óperas em voga; o desfile dos ranchos se fazia marcado pelos ritmos africanos" 12 .

A partir da década de trinta surge uma nova fase do carnaval brasileiro que começa a sentir a influência das transformações sociais e econômicas e do surgimento de novos meios de comunicação de massa (inicialmente o rádio e depois a televisão).

Assim, o carnaval "veneziano" começa a desaparecer rapidamente, permanecendo apenas os bailes à fantasia. No Rio de Janeiro, os cortejos de blocos e ranchos crescem em importância, dando origem às escolas de samba que passam a se constituir na forma predominante de desfile, formando um padrão que tende a se reproduzir na maioria das grandes cidades. 12 Pereira de Queiroz, Maria Isaura. Evolução do carnaval latino-americano. Ciência e
Cultura, 32 (11): 1481, 1980. 
O rádio, que começa na década de vinte, e se expande rapidamente na década de trinta através da publicidade, vai se tornar nesta época o meio de comunicação hegemônico até ser suplantado pela televisão que surge na década de cinquenta. Ele possibilita a comercialização do samba, permitindo desta forma a difusão e consumo por outras camadas sociais de uma manifestação cultural inicialmente restrita ao "morro".

Além dos meios de comunicação, o Estado também tem um papel fundamental neste processo, já que percebe a importância política das agremiações carnavalescas. Assim, a partir de 1935 as escolas de samba são reconhecidas, legalizadas e obrigadas a se registrar como entidades sob o nome de Grêmio Recreativo Escola de Samba. Os seus desfiles são então oficializados e financiados pelo Estado. A partir desta época, como todas as escolas são "solicitadas a colaborar com a propaganda patriótica oficial, eminentemente ufanista, iniciouse a tradição da escolha de enredos capazes de estimular o amor popular pelos símbolos da pátria e as glórias nacionais" ${ }^{13}$. Neste sentido, cabe ressaltar que entre 1943 e 1945 os concursos oficiais de desfiles de escolas de samba são patrocinados pela Liga de Defesa Nacional, estando a entrega de prêmios a cargo de um general do Exército.

As décadas seguintes mostram que, com o desenvolvimento da indústria cultural e do turismo, ocorre com o carnaval popular um processo semelhante ao já ocorrido em relação ao samba. "A partir dos anos 60, a escola de samba, (...) a qual já havia sido incentivada pelo setor comercial e pelos poderes públicos, passa a ser encarada como uma mercadoria passível de ser comercializada não somente junto a turistas estrangeiros e nacionais mas junto aos próprios meios de comunicação de massa, principalmente a televisão. Assim um folguedo carnavalesco típico de uma parte da população de uma determinada cidade é veiculado, via televisão, para todo o território

\footnotetext{
13 Tinhorão, José Ramos. Pequena história da música popular. Petrópolis, Vozes, 1975,
} p. 173 . nacional e agora sob a forma de uma manifestação cultural altamente valorizada pela sociedade (...)" ${ }^{14}$.

É claro que aquilo que ocorreu historicamente com o carnaval é um processo bastante complexo. Trata-se de uma manifestação cultural de origem européia que foi até aproximadamente 1930 mantida com aspectos muito pouco brasileiros e sob a hegemonia das classes dominantes. Quando as classes populares começam a criar formas próprias e nacionais de brincar o carnaval, estas são inicialmente perseguidas, depois toleradas e finalmente apropriadas - através do Estado e dos meios de comunicação de massa - e transformadas em símbolos nacionais.

Apesar de terem se apoderado do carnaval, as classes dominadas tiveram, por seu turno, o seu carnaval reapropriado e transformado em artigo de consumo e turismo e em símbolo de identidade nacional.

Um processo semelhante ocorreu em relação ao futebol, que foi trazido ao Brasil no final do século passado por jovens de famílias abastadas que foram estudar na Inglaterra. Inicialmente, à semelhança do que ocorre hoje com o tênis, o futebol estava restrito às camadas superiores das grandes cidades brasileiras e era disputado sob forma amadora em competições assistidas pela "nata" da sociedade.

Sodré argumenta que "no início (nas três primeiras décadas deste século), o futebol funcionou basicamente como um rito discriminatório de classes. Era um privilégio de brancos ricos (possivelmente um comportamento de conciliação entre comerciantes, latifundiários e estrangeiros), que excluía os nativos pobres (...)" ${ }^{\prime 15}$.

\footnotetext{
14 Simson, Olga R. de Moraes von.Transformações culturais, criatividade popular e comunicação de massa: o carnaval brasileiro ao longo do tempo. Trabalho apresentado no IV Encontro Anual da Associação Nacional de Pós-Graduação e Pesquisa em Ciências Sociais, no grupo de trabalho "Sociologia da Cultura Brasileira", realizado no Rio de Janeiro, em outubro de 1980. Mimeo., p. 7.

${ }^{15}$ Sodré, Muniz. Futebol, teatro ou televisão?, in: - O monopólio da fala. Petrópolis, Vozes, 1977, p.148.
} 
Entretanto, a partir do final da década de vinte, o significado do futebol altera-se. A consolidação de uma sociedade urbano-industrial no Brasil e a entrada das massas no cenário político, via populismo, reflete-se no futebol que adquire um crescente aspecto de espetáculo de massas executado por jogadores profissionais provindos de camadas populares, frequentemente negros, que viam nele uma possibilidade de ascensão social.

Atualmente, apesar de ser um esporte extremamente popular, no nível profissional o futebol envolve grandes somas de dinheiro. $\mathrm{O}$ fato de alguns jogadores profissionais serem muito bem remunerados faz com que o futebol continue representando o sonho de muitos elementos das classes subordinadas ascenderem socialmente e se presta à difusão de uma imagem de "democracia racial". Por ser, hoje, um esporte popular entre todas as classes sociais, o futebol pode ser manipulado como um poderoso símbolo de unidade nacional e coesão social e racial. Isto ficou claro com o modo pelo qual a vitória brasileira no campeonato mundial de 1970 foi utilizada pelo governo que procurou associá-la ao "milagre econômico".

Como símbolo de identidade nacional, a imagem que é veiculada através do futebol brasileiro corresponde, em boa medida, à do malandro. Há uma crença generalizada de que nosso futebol vale pela esperteza, pela criatividade e pelo improviso de nossos jogadores. Isto ficou patente depois do final da copa do mundo de 1978, quando se culparam os cartolas da CBD e o técnico da seleção - todos militares, isto é, "caxias" — de terem imposto um futebol militarizado aos nossos jogadores" 16 .

A ideia de que nosso "caráter nacional" e a influência que sobre ele teria tido o negro se revelariam no futebol fica claro no que Gilberto Freyre diz a respeito do assunto: "O nosso estilo de jogar foot-ball me parece contrastar com o dos europeus por um conjunto de qualidades de surpresa, manha, de astúcia, de ligeireza e ao mesmo tempo de brilho e de espontaneidade individual em que se exprime o

\footnotetext{
${ }^{16}$ Ver, como exemplo, Santos, Joel Rufino dos. História política do futebol. São Paulo,
} Brasiliense, 1981. 76 mesmo mulatismo de que Nilo Peçanha foi até a melhor afirmação na arte política". 17

Este capítulo está longe de ter esgotado o tema das metamorfoses da cultura brasileira; existem várias outras instâncias em que caberia aprofundar as hipóteses aqui formuladas. Somente para fornecer alguns exemplos, seria interessante examinar a dinâmica da gíria e do palavrão, as temáticas da literatura de cordel, o fenômeno dos circosteatro $^{18}$ e principalmente a televisão ${ }^{19}$ para verificar como se dá o processo de apropriação e reelaboração nestes níveis. Seria também importante analisar o que ocorre com as culturas regionais através da ação dos meios de comunicação de massa. O que significa, por exemplo, a transformação, via rádio e televisão, de cantores nordestinos em cantores nacionais?

Finalmente é importante pensar o que significa, em termos de hegemonia, a tendência de apropriar, recodificar e transformar manifestações culturais, inicialmente restritas a certos grupos, em símbolos nacionais.

Num artigo sobre a dinâmica cultural na sociedade moderna, Durham argumenta que "o grupo que reelabora e utiliza o produto cultural acabado tende a ser diferente daquele que o produziu. Estando a distinção entre produtores e consumidores de cultura presa a uma distinção de classe, a relação entre eles assume necessariamente uma conotação política, isto é, ela tem implicações em termos de poder". Assim, "as diferenças culturais aparecem, não como simples expressão de particularidades do modo de vida, mas como manifestação de oposições ou aceitações que implicam num constante reposicionamento dos grupos sociais na dinâmica das relações de classe" ${ }^{20}$.

\footnotetext{
${ }^{17}$ Freyre, Gilberto. Sociologia. Rio de Janeiro, José Olympio, 1945, v. 2, p. 421.

${ }^{18}$ Ver, como exemplo, Magnani, José Guilherme Cantor. Ideologia, lazer e cultura popular: um estudo do circo-teatro nos bairros de periferia de São Paulo. Dados, 23 (2), 1980.

${ }^{19}$ Ver, como exemplo, Milanesi, Luiz Augusto. O paraíso via Embratel. Rio de Janeiro, Paz e Terra, 1978.

${ }^{20}$ Durham, Eunice Ribeiro. A dinâmica cultural na sociedade moderna. Ensaios de Opinião (2-2): 35,1977
} 
Poder-se-ia argumentar que é justamente no processo de apropriação de manifestações culturais e sua subsequente transformação em símbolos de identidade nacional que reside umas das peculiaridades da dinâmica cultural brasileira. Não que o fenômeno não ocorra em outras culturas (o jazz nos Estados Unidos e o tango na Argentina se constituem em exemplos típicos), mas ele parece ser muito mais intenso no Brasil.

Analisando os motivos pelos quais no Brasil os produtores de símbolos nacionais e da cultura de massa elegeram itens culturais produzidos originalmente por grupos dominados, Fry sugere que a incorporação destes símbolos apresentava vantagens políticas, servindo para manter a dominação disfarçada sob outro nome. Deste modo, "a conversão de símbolos étnicos em símbolos nacionais não apenas oculta uma situação de dominação racial mas torna muito mais difícil a tarefa de denunciá-la. Quando se convertem símbolos de 'fronteiras' étnicas em símbolos que afirmam os limites da nacionalidade, converte-se o que era originalmente perigoso em algo 'limpo', 'seguro' e 'domesticado'” ${ }^{21}$.

O que se observa na cultura brasileira é um fenômeno muito peculiar. Em vários países desenvolvidos e de tradição democrática, as diferenças sociais foram consideravelmente reduzidas e o acesso aos benefícios econômicos e aos direitos civis foi ampliado. Entretanto, frequentemente, as fronteiras culturais continuam bem demarcadas, o que ocorre tanto em sociedades relativamente novas como a norteamericana (onde, apesar de ter acontecido com o jazz um fenômeno parecido com o da feijoada, as fronteiras étnicas continuam bem delimitadas), como em sociedades mais antigas como a inglesa (onde as diferenças sociais transparecem inclusive em nível de sotaque, para não mencionar a questão da nacionalidade).

Em nenhuma destas sociedades existe a crença num ethos próprio originado a partir de um processo de apropriação e reelaboração de símbolos culturais. O que parece caracterizar o Brasil é justamente o fato de ser uma sociedade de imensas diferenças sociais e econômicas, na qual se verifica uma tendência de transformar manifestações culturais em símbolos de coesão social, que são manipulados como formas de identidade nacional.

\footnotetext{
${ }^{21}$ Fry, op. cit., p. 47.
} 


\section{Capítulo V}

\section{A CULTURA BRASILEIRA E A IDENTIDADE NACIONAL NA DÉCADA DE OITENTA*}

Pensar a questão cultural brasileira na década de oitenta não é um mero exercício inócuo de futurologia, mas significa procurar captar um dos aspectos cruciais para a compreensão da dinâmica da sociedade brasileira.

Para realizar esta tarefa, entretanto, é preciso considerar a década de oitenta não como um corte, mas como a continuação de processos e mudanças que vêm ocorrendo no interior da sociedade brasileira.

Neste sentido é interessante retomar algumas das antigas questões e analisar de que maneira elas são reatualizadas no presente. Uma destas questões está relacionada com a especificidade e o grau de autenticidade daquilo que é chamado de cultura brasileira e por conseguinte preocupa-se com seu poder de conscientização ou de alienação.

No bojo desta problemática está a questão de descobrir o que é apresentado como a identidade nacional e a contribuição que diferentes classes sociais prestariam para a formação desta identidade. Ou seja, evidenciar qual a classe social que é considerada representativa da nacionalidade brasileira.

O pensamento da nossa intelectualidade tem oscilado no que diz respeito a estas questões. Assim, em certos momentos nossa cultura é profundamente desvalorizada por nossas elites, tomando-se em seu

\footnotetext{
* Texto apresentado no I Seminário sobre Cultura Brasileira realizado em junho de 1980, em Ouro Preto, pelo Grupo de Trabalho "Sociologia da Cultura Brasileira" da Associação Nacional de Pós-Graduação e Pesquisa em Ciências Sociais e no V Encontro Nacional da mesma organização realizado em outubro de 1981, em Nova Friburgo. Publicado originalmente em Ciência e Cultura (34), 1982.
}

lugar a cultura européia (ou mais recentemente a norte-americana) como modelo. Como reação, em outros momentos nota-se que certas manifestações da cultura brasileira passam a ser profundamente valorizadas, exaltando-se símbolos como Macunaíma, a figura do malandro, o carnaval, o samba, o futebol, etc.

A mesma oscilação pode ser verificada no que diz respeito ao tipo social que é apresentado como representativo da nacionalidade: ele passa do fazendeiro, durante o Império e a Primeira República, ao "povo" (englobando trabalhadores urbanos, intelectuais progressistas e empresários nacionais) durante o período populista, ao tecnoburocrata, o militar e a classe média no período pós-1964.

A escolha do tipo social considerado como representativo da nacionalidade remete à questão paralela de decidir quem são os produtores válidos da cultura brasileira e, em última análise, de determinar o que é considerado como cultura.

Uma primeira perspectiva tende a considerar como cultura brasileira tão-somente aquelas manifestações intelectuais e artísticas da elite ${ }^{1}$. Uma perspectiva pretensamente alternativa tende a valorizar as manifestações culturais das classes dominadas como as verdadeiras raízes de nossa nacionalidade. Mas esta valorização é feita sob uma ótica nostálgica e frequentemente ufanista. Assim, parte de nossa intelectualidade apressa-se a "defender" a cultura popular dos ataques que o progresso estaria lhe desferindo, adotando uma postura paternalista e essencialmente museológica.

Em verdade, o que se percebe é que no primeiro tipo de colocação proclama-se a existência de uma Cultura Brasileira com "C" maiúsculo que, embora produzida por apenas um grupo social restrito, seria válida para toda a nação e, inversamente, no segundo tipo de colocação erige-se uma imagem cristalizada das manifestações culturais que nossas classes subalternas teriam desenvolvido no passado.

\footnotetext{
1 Para uma análise crítica desta perspectiva ver, entre outros, Mota, Carlos Guilherme. Ideologia da cultura brasileira (1933-1974). São Paulo, Ática, 1977 e Miceli, Sérgio. Intelectuais e classe dirigente no Brasil (1920-1945). São Paulo, DIFEL, 1979.
} 
O que estas perspectivas não conseguem perceber é a relação que existe entre as classes sociais no processo de produção cultural. Aqui, é claro, não se trata de proclamar simplisticamente que a cultura da classe dominante é a cultura dominante, mas dar-se conta de que existe um processo de apropriação e reelaboração cultural. Este processo é complexo e convém explicitá-lo.

Assim, em certos momentos, o que é considerado como cultura brasileira é a apropriação e reelaboração por parte de nossas classes dominantes de traços culturais gerados nas metrópoles que são tidas como os únicos dignos de serem adotados pelas elites.

Analisando, por exemplo, as transformações culturais que se operaram nas camadas superiores da cidade do Rio e Janeiro por ocasião da vinda da família real portuguesa ao Brasil, Maria Isaura Pereira de Queiroz ${ }^{2}$ formulou a hipótese de que a difusão de um modo de vida burguês começou a ocorrer no Brasil aproximadamente a partir de 1820, muito antes de o país começar a se tornar industrializado. De acordo com aquela autora, este modo de vida diferenciou a população não somente segundo níveis econômicos, mas principalmente do ponto de vista cultural, já que os estratos superiores adotaram o requinte e o arremedo de vida intelectual européia como símbolo de distinção. Não seria difícil apontar outras situações em que este processo de aparente defasagem ocorreu com nossas elites. No plano das ideias, por exemplo, Schwarz ${ }^{3}$ procurou mostrar como a ideologia liberal originária da Europa estava "fora do lugar" no Brasil Império, uma sociedade baseada na escravidão na qual a categoria fundamental não era consubstanciada nos direitos burgueses mas nos favores paternalistas.

O processo inverso ao que acaba de ser descrito é representado pela valorização daquilo que seria mais autenticamente brasileiro. Esta tendência já comparece no século passado nos escritos dos representantes da escola indianista da nossa literatura e atinge seu

${ }^{2}$ Pereira de Queiroz, Maria Isaura. Do rural e do urbano no Brasil, in: Szmrecsányi, Tamás \& Queda, Oriowaldo, orgs. Vida rural e mudança social. São Paulo, Nacional, 1973, p. 210. ${ }^{3}$ Schwarz, Roberto. As ideias fora do lugar, in: - . Ao vencedor as batatas. São Paulo, Duas Cidades, 1977. apogeu nos romances de José de Alencar, nos quais valorizam-se nossas raízes nacionais: o índio, a vida rural, etc ${ }^{4}$.

Mas se os autores românticos exaltam as virtudes do caráter brasileiro, eles são sucedidos por uma série de intelectuais como Sílvio Romero, Euclides da Cunha, Nina Rodrigues, Oliveira Vianna e Arthur Ramos que, preocupados em explicar a sociedade brasileira através da interação da raça e do meio geográfico, são profundamente pessimistas e preconceituosos em relação ao brasileiro que é caracterizado entre outras coisas como apático e indolente, e a nossa vida intelectual destituída de filosofia e ciência e eivada de um lirismo subjetivista e mórbido.

Parece que o movimento modernista de 1922, com toda sua complexidade e diferenciação ideológica, representa um divisor de águas neste processo. Por um lado significa a reatualização do Brasil em relação aos movimentos culturais e artísticos que ocorrem no exterior; por outro lado implica também em buscar nossas raízes nacionais valorizando o que haveria de mais autêntico no Brasil. Obviamente não é casual que o movimento tenha tido sua sede em São Paulo, a cidade que já começava sua trajetória de metrópole industrial, assim como não é casual que o movimento tradicionalista de 1926 tenha surgido em Recife, a capital mais desenvolvida do Nordeste ${ }^{5}$.

É significativo que é a partir desta época que as ideologias do caráter nacional brasileiro ganham uma nova dimensão. O que se observa é a elaboração de dois modelos básicos construídos a partir de uma questão comum. A suposição eurocêntrica de que seria impossível construir uma civilização nos trópicos é tomada como um desafio a ser vencido.

A primeira solução consiste em apostar na seriedade do brasileiro e afirmar que havendo esforço e líderes é possível fazer vingar uma civilização nestas terras. Esta vertente é simbolizada pelo mundo da

\footnotetext{
4 Ver, a este respeito, Pereira de Queiroz, Maria Isaura. Cientistas sociais e o autoconhecimento da cultura brasileira através do tempo. Cadernos CERU (13), 1980.

5 Ver, Freyre, Gilberto. Manifesto Regionalista. Recife, Instituto Joaquim Nabuco de Pesquisas Sociais, 1976.
} 
"ordem e progresso" e vai encontrar seu desenvolvimento na imagem do "caxias", do "povo ordeiro" e, mais recentemente, do "este é um país que vai para frente" e do "vamos trabalhar para vencer a crise". Esta visão perpassa nossa história recente e é apresentada constantemente por uma parte de nossas classes dominantes e intelectuais a seu serviço como a verdadeira imagem do Brasil.

A solução pretensamente alternativa ao desafio de construir uma civilização nos trópicos, embora seja aparentemente menos rígida, é tão ideológica quanto a primeira e representa a outra face da mesma moeda. Ela é o resultado de uma resposta muito peculiar ao desafio de construir uma civilização nos trópicos e de uma maneira caricata segue o seguinte raciocínio: Sabemos que o velho Freud ensinava que a civilização e a cultura são frutos da repressão, e que um personagem de Dostoievski afirmava que se Deus não existe tudo é permitido. Ocorre, como todo mundo sabe, que Deus é brasileiro e, se não existe pecado do lado de baixo do Equador, é preciso perguntar que tipo de cultura pode haver no Patropi, pois não existindo pecado não há o que reprimir.

A resposta a este dilema é que aqui só é possível um tipo muito especial de cultura já que as categorias racionais não funcionariam nos trópicos. A imagem que é proposta é a de uma cultura tropical com características totalmente diferentes de outros países.

O efeito desta proposta é a tentativa de sugerir um ethos brasileiro que seria único e intraduzível. Assim como nos orgulhamos da impossibilidade de traduzir a palavra saudade, nos orgulharíamos também de nossas características igualmente impossíveis de serem captadas pelos estrangeiros: o jeitinho, o galho quebrado, a malandragem, a sacanagem, a malícia, o dengue, a sensualidade, a inzona, etc. Enfim, o Brasil não seria passível de redução a categorias racionais porque nos trópicos a razão se derrete e tudo e todos se misturam gostosamente numa grande loucura.

É revelador que nas diferentes variantes destes dois modelos de construção de identidade, o que se desenvolve é um tipo que tem mais conotação de nacionalidade e/ou raça que de classes. É nesta perspectiva que se encontram soluções como a figura do "caxias", Macunaíma (nosso herói sem nenhum caráter), o homem cordial, o malandro e a ideia tão bem captada por Oswald de Andrade de que no Brasil, diferentemente da Europa, o contrário do burguês não seria o proletário, mas o boêmio.

Simultaneamente à formação destas duas imagens, percebe-se também um processo através do qual manifestações culturais, que se originam nas classes dominadas, e que são inclusive inicialmente às vezes reprimidas, passam a ser apropriadas pelas classes dominantes e através de um processo de manipulação de seu significado são transformadas em símbolos nacionais. Exemplos disto são o samba, o tema da malandragem, a Umbanda, a feijoada, manifestações que tiveram origens populares e que foram posteriormente transformadas em símbolos nacionais.

É neste processo de apropriação de manifestações populares e sua manipulação e subsequente transformação em símbolos de identidade nacional que talvez resida uma das peculiaridades da dinâmica cultural brasileira. Não é que o fenômeno não ocorra em outras culturas (o jazz nos Estados Unidos se constitui num exemplo típico), mas o fenômeno parece ser muito mais intenso no Brasil.

É importante assinalar que este processo tem início num momento de grandes transformações sociais, econômicas e políticas, em que o mercado nacional se consolida e a indústria passa a ser uma categoria cada vez mais importante. É essa também a época em que se desenvolve a indústria cultural no Brasil, o rádio surgindo na década de vinte e mantendo sua hegemonia até a implantação da televisão nos anos cinquenta.

Mesmo durante o intervalo democrático de 1946-64 a problemática cultural retoma algumas das questões até aqui discutidas. Assim, se entidades como o CPC (Centro Popular de Cultura) e o ISEB (Instituto Superior de Estudos Brasileiros) recusavam a imagem do brasileiro através de características como a cordialidade ou a bondade, preferindo em vez disto apostar no que lhes parecia ser a cultura popular e na construção de um projeto nacional progressista, 
alguns de seus representantes, como Roland Corbisier, falavam na "essência" da cultura brasileira ${ }^{6}$.

Neste período, a acusação que pairava em relação aos intelectuais brasileiros era de que grande parte deles eram colonizados e ajudavam a criar uma cultura alienada, fruto de nossa situação de dependência. Haveria, portanto, a necessidade de uma vanguarda que ajudasse a produzir uma autêntica cultura nacional para o povo, esta categoria tão vaga e policlassista.

Além de retomar um dos temas do modernismo, o movimento tropicalista que surge em 1968 teve como um de seus méritos mostrar que a realidade mudou muito depois de 1964 e que não fazia mais sentido continuar batendo nas antigas teclas. $\mathrm{O}$ que se verificou foi que a intensificação da acumulação capitalista, com a ajuda do capital estrangeiro, criou uma nova situação não somente do ponto de vista econômico e político, mas também cultural.

De fato, depois de 1964 o panorama cultural se alterou substancialmente. A intensificação da penetração do capital estrangeiro significou uma nova substituição de importações, criando uma situação em que se produzem praticamente todos os bens de consumo dentro das fronteiras nacionais. A internalização da produção de mercadorias, obviamente, inclui a indústria cultural. Assim, um conglomerado como a Rede Globo, apesar de iniciado por capitais estrangeiros, substitui cada vez mais os enlatados do exterior por programas made in Brazil, cuja qualidade técnica permite que eles sejam inclusive exportados.

$\mathrm{O}$ fato de os programas serem produzidos no Brasil, abordando situações tipicamente brasileiras, é menos importante que o tratamento que lhes é dado e as ideologias que lhe são subjacentes, verificando-se que os meios de comunicação de massa em geral e a televisão em particular se apropriam de temas que fazem parte do cotidiano nacional e reelaboram-nos, concedendo-lhes uma formulação ideológica que tenha trânsito fácil.

${ }^{6}$ Ver, a este respeito, Ortiz, Renato. Cultura popular: organização e ideologia. Cadernos de Opinião (12), 1979 e Id. Cultura popular e memória nacional. Cadernos CERU (13), 1980.
A televisão, assim como outros meios de comunicação de massa, é com frequência vista ou como exercendo um efeito desagregador sobre as culturas regionais (na medida em que impõe ao resto do país padrões restritos à zona sul do Rio de Janeiro), ou contrariamente como tendo uma função aglutinadora na medida em que integra a nação sob o ponto de vista cultural. O importante é se dar conta que por trás destes processos complementares existe uma tentativa de criar uma hegemonia, o que transparece tanto nos programas de auditório como nos arquétipos das telenovelas, que de certo modo se dirigem ao que Gramsci chamava de "paixões elementares do povo""

Miceli captou bem este processo ao sugerir que na atual fase da sociedade brasileira, "os meios de comunicação de massa em geral, e a televisão, em particular, constituem os veículos de uma ação 'pedagógica' a serviço do processo de unificação do mercado material e simbólico, que se traduz pela imposição 'diferencial' da cultura dominante"

Neste sentido nunca é demais lembrar que os canais de televisão e de rádio são concessões estatais que podem ser revogadas a qualquer momento e que o controle do Estado se faz sentir em relação à cultura pelo menos desde a criação da indústria cultural. A interferência estatal em relação à cultura se acentua justamente na década de trinta quando começa a se consolidar uma sociedade urbano-industrial no Brasil. Por isto é revelador que uma das preocupações centrais do DIP (Departamento de Imprensa e Propaganda) na época do Estado Novo foi a de inverter na música popular brasileira a tendência à exaltação da malandragem e incentivar por todos os meios a valorização do trabalho. Esta ideia de seriedade - ligada à necessidade de disciplinar uma força de trabalho assalariada - foi também acompanhada de outro tipo de ideologia que lhe é concomitante: "a glorificação de determinado brasileiro - sestroso, fuleiro, pachola — em sambas que pintavam o Brasil com aquelas mesmas cores do arco-íris já tomadas anteriormente de empréstimo pelos poetas mais conservadores do

\footnotetext{
${ }^{7}$ Gramsci, Antônio. Concepção dialética da História. Rio de Janeiro, Civilização Brasileira, 1978, p. 139.
}

${ }^{8}$ Miceli, Sérgio. A noite da madrinha. São Paulo, Perspectiva, 1972, p. 218. 
modernismo, como Cassiano Ricardo e Menotti del Picchia, doutrinados por Plínio Salgado. Nessa fase da música popular, as mesmas obsessões daqueles poetas retornam em composições de Ary Barroso e Dorival Caymmi, só que com força total: as lendas do 'povo ordeiro', da 'história incruenta' e da 'suave mistura de raças" ",

O que já se pode observar naquela época é o desenvolvimento de duas tendências complementares do Estado em relação à cultura: ele interfere proibindo e censurando aquilo que é visto como prejudicial à imagem "séria" do Brasil, mas, em contrapartida, atua promovendo a imagem sui generis de nossa cultura.

A primeira tendência se evidencia quando o Estado aposta na ideologia da seriedade e do produtivismo, o que transparece na época do DIP pela tentativa de inverter a exaltação da malandragem em exaltação do trabalho e na época da AERP (Assessoria Especial de Relações Públicas do Governo Médici) e da SECOM (Secretaria de Comunicação Social do Governo Figueiredo) pela promoção de um produtivismo cínico do tipo "Vamos trabalhar que a gente pega a inflação na esquina"; a segunda tendência se evidencia, também na década de trinta, quando o Estado se apodera de uma manifestação espontânea como o carnaval e, oficializando seus desfiles, pressiona as escolas de samba a criarem enredos que exaltem a grandeza nacional (situação bem satirizada no Samba do Crioulo Doido) e mais recentemente na época do Governo Médici quando a AERP procurou transformar uma manifestação popular como o futebol em símbolo máximo de integração nacional, apresentando a conquista da Copa do Mundo como fruto do gênio, da garra e do jeitinho nacional, qualidades supostamente exclusivas do povo brasileiro.

Neste último exemplo, a AERP conseguiu inclusive a façanha de criar, através do slogan "Ninguém segura este país", a ideia da articulação da genialidade da nação brasileira com o "milagre econômico", embuste que começou a ficar desmascarado quando a nação passou a se dar conta de que o futebol não segurava mais este

\footnotetext{
${ }^{9}$ Castro, Ruy. Brasil rima com anil. Isto É (77): 38, 19 jun. 1978.
}

país. Entretanto, a crescente intervenção do Estado no futebol evidencia sua importância simbólica e ideológica.

Como se pode ver, o papel do Estado em relação à cultura é complexo: ele não é apenas o agente de repressão e de censura, mas também o incentivador da produção cultural e, acima de tudo, o criador de uma imagem integrada do Brasil que tenta se apropriar do monopólio da memória nacional.

Embora durante parte da década de sessenta e de setenta a cultura tenha sido frequentemente encarada mais como um reduto de subversão, é importante constatar que o Estado simultaneamente começou a assumir o papel de usar a cultura como um espaço para a construção de um projeto de hegemonia.

Se no começo da década de sessenta o regionalismo, especialmente o nordestino, era visto como um dos temas mais candentes da nacionalidade, o Estado e os meios de comunicação se apropriam desta temática através de uma manipulação que a transforma em assunto trivial e anódino, criando programas que procuram valorizar "aquilo que é nosso". Em programas radiofônicos como o Minerva em Ação Cultural e Domingo Mobral, isto significa não só divulgar músicas como, por exemplo, os ternos de reis de alguma região brasileira como algo que precisa ser lembrado e valorizado, mas também no mesmo programa atender a solicitação de um ouvinte que deseja ouvir uma música de Roberto Carlos. Pois, nesta proposta, o Brasil seria justamente esta soma colorida e tropical de manifestações regionais (apresentadas de um modo museológico e tendendo para o exótico e turístico) que precisam ser conhecidas e valorizadas junto com as criações produzidas nos grandes centros e que são divulgadas nas mais distantes áreas do país como forma de modernidade $\mathrm{e}$ integração.

O Estado avoca a si o papel de manter acesa a chama da memória nacional e por conseguinte se transforma no criador e bastião da identidade nacional. $\mathrm{O}$ fato de este mesmo Estado permitir a crescente desnacionalização de nossa economia não é assumido como contraditório já que estas duas questões são propostas como desvinculadas. É importante lembrar que são justamente grandes 
empresas estrangeiras como a Shell e a Xerox que fazem a defesa de nosso folclore em suas publicidades.

É nisto que consiste a tentativa de substituir um modelo fundamentalmente baseado na coerção por um modelo ancorado na hegemonia que funcionaria basicamente em termos de manipular símbolos nacionais.

O grande obstáculo a este projeto de hegemonia é que ele está desvinculado da questão sócio-econômica. À medida que a ordem burguesa se consolida no Brasil, o Estado tenta criar um projeto que privilegia o cultural, sem querer alterar fundamentalmente as regras da ordem econômica e política. Assim, através de uma abertura restrita, do afrouxamento da censura e de uma reforma partidária que visa à reordenação do poder pelo alto se pretende soldar a sociedade sem modificar substancialmente questões-chave como a legislação trabalhista, a distribuição de renda, a posse da terra, etc. $\mathrm{O}$ projeto obviamente é tão precário que o próprio crescimento da inflação coloca em questão a sua viabilidade.

Uma questão fundamental que provavelmente se colocará com maior intensidade, portanto, é a da existência de dois movimentos contrários que se farão sentir mais marcadamente nesta década: por um lado, à medida que uma ordem burguesa se consolida no Brasil acentuar-se-á a tentativa de construir uma hegemonia através dos meios de comunicação de massa e do Estado. Por outro lado, se houver uma crescente mobilização da sociedade civil, é possível que as classes subalternas possam se organizar melhor e encontrar mais canais de expressão e formas de reelaborar as mensagens e ideologias recebidas através do Estado e dos meios de comunicação de massa.

\section{BIBLIOGRAFIA}

AGUIAR BARROS, J. M. de. A utilização político-ideológica da delinquência. Encontros com a Civilização Brasileira (20), 1980

ALMEIDA, Manuel Antônio de. Memórias de um sargento de milícias. São Paulo, Ática, 1979.

ASSIS, Machado. O alienista. São Paulo, Ática, 1981.

BERLINCK, Manuel Tosta. Sossega leão: algumas considerações sobre o samba como forma de cultura popular. Contexto (1), 1976.

BROWN, Diana. O papel histórico da classe média na Umbanda. Religião e Sociedade (1), 1977.

BUARQUE DE HOLLANDA, Chico. Ópera do malandro. São Paulo, Cultura, 1979

BUARQUE DE HOLLANDA, Sérgio. Raízes do Brasil. Rio de Janeiro, José Olympio, 1936.

CABRAL, Sérgio. Getúlio Vargas e a música popular brasileira. Ensaios de Opinião (2-1), 1975.

CÂNDIDO, Antônio. Dialética da malandragem. Revista do Instituto de Estudos Brasileiros (8), 1970.

CHEVALIER, Louis. Classes laborieuses et classes dangereuses à Paris, pendant la première moitié du XIX ${ }^{e}$ siècle. Paris, Librarie Générale Française, 1978

COSTA, Manuel Augusto. Urbanização e migração urbana no Brasil. Rio de Janeiro, IPEA/INPES, 1975.

CRUZ, H. Dias da. Os morros cariocas no novo regime. Rio de Janeiro, Gráfica Olímpica, 1941.

DA MAT'TA, Roberto. Carnavais, malandros e heróis. Rio de Janeiro, Zahar, 1979

—. Ensaios de antropologia estrutural. Petrópolis, Vozes, 1973. 
DURHAM, Eunice Ribeiro. A dinâmica cultural na sociedade moderna. Ensaios de Opinião (2-2), 1977.

FONSECA. Rubem. Feliz ano novo. Rio de Janeiro, Artenova, 1975.

—. O cobrador. Nova Fronteira, 1979.

FRANCO, Maria Sylvia de Carvalho. Homens livres na ordem escravocrata. São Paulo, Ática, 1974.

FREYRE, Gilberto. Manifesto Regionalista. Recife, Instituto Joaquim Nabuco de Pesquisas Sociais, 1976.

—. Sociologia. Rio de Janeiro, José Olympio, 1945.

FRY, Peter. Feijoada e soul food: notas sobre a manipulação de símbolos étnicos e nacionais. Ensaios de Opinião (2-2), 1977.

GRAMSCI, Antônio. Concepção dialética da História. Rio de Janeiro, Civilização Brasileira, 1978.

HALL, Stuart; CRITCHER, Chas; JEFFERSON, John \& ROBERTS, Brian. Policing the crisis: mugging, the State, and law and order. Londres, MacMillan, 1978.

HERD, Erika Francziska. A importância política do rádio. Revista de Cultura Vozes, 73 (8), 1979.

LODDER, Celsius A. Distribuição de renda nas áreas metropolitanas. Rio de Janeiro, IPEA/INPES, 1976.

MAGNANI, José Guilherme Cantor. Ideologia, lazer e cultura popular: um estudo do circo-teatro nos bairros de periferia de São Paulo. Dados, 23 (2), 1980.

MENEZES, Eduardo Diatay B. de. Elitelore versus folclore, ou de como a cultura hegemônica tende a devorar a cultura subalterna. Trabalho apresentado no I Seminário de Cultura Brasileira realizado em julho de 1980, em Ouro Preto, pelo Grupo de Trabalho "Sociologia da Cultura Brasileira" da Associação Nacional de Pós-Graduação e Pesquisa em Ciências Sociais.

MICELI, Sérgio. A noite da madrinha. São Paulo, Perspectiva, 1972.

-. Intelectuais e classe dirigente no Brasil (1920-1945).
MILANESI, Luiz Augusto. O paraíso via Embratel. Rio de Janeiro, Paz e Terra, 1978

MOOG, Vianna. Bandeirantes e Pioneiros. Rio de Janeiro, Civilização Brasileira, 1966.

MOTA, Carlos Guilherme. Cultura e política no Estado Novo (1937-1945). Encontros com a Civilização Brasileira (7), 1979.

—. Ideologia da cultura brasileira (1933-1974). São Paulo, Ática, 1977.

OLIVEN, Ruben George. Urbanização e mudança social no Brasil. Petrópolis, Vozes, 1980.

ORTIZ, Renato. A morte branca do feiticeiro negro: Umbanda, integração de uma religião numa sociedade de classes. Petrópolis, Vozes, 1978.

—. Cultura popular e memória nacional. Cadernos CERU (13), 1980.

- Cultura popular: organização e ideologia. Cadernos de Opinião (12), 1979.

PEREIRA DE QUEIROZ, Maria Isaura. Cientistas sociais e o autoconhecimento da cultura brasileira através do tempo. Cadernos CERU (13), 1980.

-. Do rural e do urbano no Brasil. In: SZMRECSÁNYI, Tamás \& QUEDA, Oriowaldo, orgs. Vida rural e mudança social. São Paulo, Nacional, 1973.

—. Evolução do carnaval latino-americano. Ciência e Cultura, 32 (11), 1980.

PINHEIRO, Paulo Sérgio. Violência do Estado e classes populares. Dados (22), 1979.

SANT'ANNA, Affonso Romano de. Música popular e moderna poesia brasileira. Petrópolis, Vozes, 1977.

SANTOS, Joel Rufino dos. História política do futebol. São Paulo, Brasiliense, 1981

SCHWARZ, Roberto. Ao vencedor as batatas. São Paulo, Duas Cidades, 1977. 
-. Pressupostos, salvo engano, da "Dialética da Malandragem". Ensaios de Opinião (13), 1979.

SIMSON, Olga R. de Moraes von. Transformações culturais, criatividade popular e comunicação de massa: o carnaval brasileiro ao longo do tempo. Trabalho apresentado no IV Encontro Anual da Associação Nacional de Pós-Graduação e Pesquisa em Ciências Sociais, no grupo de trabalho "Sociologia da Cultura Brasileira", realizado no Rio de Janeiro, em outubro de 1980.

SODRÉ, Muniz. O monopólio da fala. Petrdpolis, Vozes, 1977.

-. Samba, o dono do corpo. Rio de Janeiro, Codecri, 1979.

TINHORÃO, José Ramos. Pequena história da música popular. Petrópolis, Vozes, 1975.

VASCONCELLOS, Gilberto. Música popular: de olho na fresta. Rio de Janeiro, Graal, 1977.

VIANNA, Luiz Werneck. O americanismo: da pirataria à modernização (e o que se pode seguir). In: BUARQUE DE HOLLANDA, Chico. Ópera do malandro. São Paulo, Cultura, 1979.

WEBER, Max. A ética protestante e o espírito do capitalismo. São Paulo, Pioneira, 1967.

YAP, Lorene. Internal migration and economic development in Brazil. Tese de doutorado, Harvard University, 1972. 